\title{
P2Y Purinoceptors Inhibit Exocytosis in Adrenal Chromaffin Cells via Modulation of Voltage-Operated Calcium Channels
}

\author{
Andrew D. Powell, Anja G. Teschemacher, and Elizabeth P. Seward \\ Department of Pharmacology, University of Bristol, Bristol, BS8 1TD, United Kingdom
}

We have used combined membrane capacitance measurements $\left(C_{m}\right)$ and voltage-clamp recordings to examine the mechanisms underlying modulation of stimulus-secretion coupling by a $\mathrm{G}_{\mathrm{i} / \mathrm{o}}$-coupled purinoceptor (P2Y) in adrenal chromaffin cells. P2Y purinoceptors respond to extracellular ATP and are thought to provide an important inhibitory feedback regulation of catecholamine release from central and sympathetic neurons. Inhibition of neurosecretion by other $\mathrm{G}_{\mathrm{i} / \mathrm{o}}$-proteincoupled receptors may occur by either inhibition of voltageoperated $\mathrm{Ca}^{2+}$ channels or modulation of the exocytotic machinery itself. In this study, we show that the P2Y purinoceptor agonist 2-methylthio ATP (2-MeSATP) significantly inhibits $\mathrm{Ca}^{2+}$ entry and changes in $C_{\mathrm{m}}$ evoked by single $200 \mathrm{msec}$ depolarizations or a train of $20 \mathrm{msec}$ depolarizations $(2.5 \mathrm{~Hz})$. We found that P2Y modulation of secretion declines during a train such that only $\sim 50 \%$ of the modulatory effect remains at the end of a train. The inhibition of both $\mathrm{Ca}^{2+}$ entry and $\Delta C_{\mathrm{m}}$ are also attenuated by large depolarizing prepulses and treatment with pertussis toxin. Inhibition of N-type, and to lesser extent $\mathrm{P} / \mathrm{Q}$-type, $\mathrm{Ca}^{2+}$ channels contribute to the modulation of exocytosis by 2-MeSATP. The $\mathrm{Ca}^{2+}$-dependence of exocytosis triggered by either single pulses or trains of depolarizations was unaffected by 2-MeSATP. When $\mathrm{Ca}^{2+}$ channels were bypassed and exocytosis was evoked by flash photolysis of caged $\mathrm{Ca}^{2+}$, the inhibitory effect of 2-MeSATP was not observed. Collectively, these data suggest that inhibition of exocytosis by $\mathrm{G}_{\mathrm{i} / \mathrm{o}}$-coupled P2Y purinoceptors results from inhibition of $\mathrm{Ca}^{2+}$ channels and the $\mathrm{Ca}^{2+}$ signal controlling exocytosis rather than a direct effect on the secretory machinery.

Key words: P2Y purinoceptor; G-protein-coupled receptor; voltage-operated calcium channels; exocytosis; modulation; presynaptic inhibition; adrenal chromaffin cells
It is now well established that ATP can act as a fast excitatory neurotransmitter by activation of postsynaptic purinoceptors (Edwards et al., 1992; Evans et al., 1992) (for review, see Zimmermann, 1994, Gibb and Halliday, 1996). Recent studies have shown that ATP may also act as a neuromodulator. Activation of presynaptic P2X purinoceptors facilitates neurotransmission (Khakh and Henderson, 1998; Boehm, 1999) (for review, see MacDermott et al., 1999), whereas activation of presynaptic P2Y purinoceptors is thought to inhibit neurotransmission (Von Kügelgen et al., 1989; Boehm, 1999). The mechanism(s) underlying inhibition of neurotransmission by P2Y purinoceptors is unknown. Presynaptic inhibition of neurotransmitter release by other G-proteincoupled receptors (GPCRs), however, is generally thought to involve either changes in membrane excitability and $\mathrm{Ca}^{2+}$ signaling or a direct effect on some component of the release machinery (Hille, 1994; Wu and Saggau, 1997; Miller, 1998). Central to the $\mathrm{Ca}^{2+}$ hypothesis for presynaptic inhibition are the observations that neuronal, somatic voltage-operated $\mathrm{Ca}^{2+}$ channels are inhibited by $\mathrm{G}_{\mathrm{i} / \mathrm{o}}$-proteins (Dolphin, 1998) and that pharmacologically similar channels control exocytosis (Dunlap et al., 1995). It is assumed that the modulatory processes that regulate $\mathrm{Ca}^{2+}$ channels in the soma also occur at release sites. The release

\footnotetext{
Received July 26, 1999; revised Oct. 28, 1999; accepted Nov. 4, 1999.

This work was supported by a project grant to E.P.S. from the Wellcome Trust and a studentship to A.D.P. from the Medical Research Council of the United Kingdom. We thank Drs. Graeme Henderson, Neil V. Marrion, and Mark Wall for helpful discussion of the work and manuscript.

Correspondence should be addressed to Dr. Elizabeth P. Seward, Department of Pharmacology, University of Bristol, University Walk, Bristol, BS8 1TD, UK. E-mail: liz.seward@bris.ac.uk.

Copyright (C) 2000 Society for Neuroscience $\quad 0270-6474 / 00 / 200606-11 \$ 15.00 / 0$
}

machinery hypothesis, on the other hand, arises from the observation that activation of GPCRs inhibits exocytosis when $\mathrm{Ca}^{2+}$ channels are bypassed or blocked (Silinsky, 1986; ManSonHing et al., 1989; Shen and Surprenant, 1990; Lang et al., 1995). Whether modulation of the release machinery contributes significantly to GPCR-dependent inhibition of stimulus-evoked neurotransmitter release is still a matter of debate (Thompson et al., 1993; Miller, 1998).

The aim of this study was to determine the mechanisms underlying modulation of exocytosis by $\mathrm{P} 2 \mathrm{Y}$ purinoceptors. The system we chose to study was the adrenal chromaffin cell because it is well established that these cells secrete catecholamines by $\mathrm{Ca}^{2+}$ regulated exocytosis (Neher, 1998) and they express inhibitory P2Y purinoceptors that couple to neuronal $\mathrm{Ca}^{2+}$ channels (Diverse-Pierluissi et al., 1991; Gandia et al., 1993; Currie and Fox, 1996). Moreover, chromaffin cells co-store and release ATP along with catecholamine (Winkler and Westhead, 1980), and it is thought that, as in sympathetic neurons (Von Kügelgen et al., 1994), ATP may act as an autocrine regulator of secretion from these cells (Carabelli et al., 1998). We used combined voltageclamp and membrane capacitance measurements $\left(C_{\mathrm{m}}\right)$ to study the effects of $\mathrm{P} 2 \mathrm{Y}$ purinoceptor activation on stimulus-secretion coupling. Our results show that the selective P2Y agonist 2-methylthio ATP (2-MeSATP) inhibited both $\mathrm{Ca}^{2+}$ channels and $\Delta C_{\mathrm{m}}$ via a voltage-dependent, pertussis toxin (PTX)sensitive mechanism. The P2Y-mediated inhibition of exocytosis was not associated with a change in the $\mathrm{Ca}^{2+}$-dependence of secretion. When $\mathrm{Ca}^{2+}$ channels were bypassed and exocytosis was stimulated by flash photolysis of nitrophenyl-EGTA (NPEGTA), 2-MeSATP had no effect on $\Delta C_{\mathrm{m}}$. These data provide strong evidence in favor of the $\mathrm{Ca}^{2+}$ hypothesis for presynaptic 
inhibition by $\mathrm{G}_{\mathrm{i} / \mathrm{o}} \mathrm{PCR}$ and may also explain feedback inhibition of catecholamine release through $\mathrm{P} 2 \mathrm{Y}$ purinoceptors.

\section{MATERIALS AND METHODS}

Chromaffin cell culture. Chromaffin cells were prepared by collagenase digestion of bovine adrenal glands according to the method of Trifaro and Lee (1981). Adrenal glands from 18- to 24-month-old cows were obtained from a local abattoir and were retrogradely perfused at 25 $\mathrm{ml} / \mathrm{min}$ for $30 \mathrm{~min}$ at $37^{\circ} \mathrm{C}$ with the digestive enzymes $0.03 \%$ collagenase type 2 (Worthington Biochemical Corp., Lakewood, NJ) and $0.0013 \%$ DNase I (Boehringer Mannheim, Indianapolis, IN) added to a Locke's solution consisting of (in mM): $154.2 \mathrm{NaCl}, 2.6 \mathrm{KCl}, 2.2 \mathrm{~K}_{2} \mathrm{HPO}_{4}, 0.85$ $\mathrm{KH}_{2} \mathrm{PO}_{4}, 10$ glucose, and 5 HEPES, with $0.0005 \%$ Phenol Red (Life Technologies, Paisley, UK), pH adjusted to 7.2 with $\mathrm{NaOH}$. After surgical removal of the cortex, the medulla was dissected, cut into small pieces, placed in a trypsinization flask with fresh enzyme solution, and stirred at slow speed for $30 \mathrm{~min}$ at $37^{\circ} \mathrm{C}$. Cells were washed twice with Earle's Balanced Salt Solution (Life Technologies) and resuspended in DMEM (Life Technologies) supplemented with $44 \mathrm{~mm} \mathrm{NaHCO}_{3}, 15 \mathrm{~mm}$ HEPES, $10 \%$ fetal calf serum (Life Technologies), $1 \%$ glutamine, $1 \%$ penicillin-streptomycin solution, $2.5 \mathrm{mg} / \mathrm{ml}$ gentamycin, $0.5 \mathrm{mg} / \mathrm{ml} 5^{\prime}$ fluorodeoxyuridine, and $0.01 \mathrm{mg} / \mathrm{ml}$ cytosine- $\beta$ - $\delta$-arabino-furanoside. Cells were plated on glass coverslips coated with matrigel (Becton Dickinson, Bedford, MA) at a density of $\sim 800$ cells $/ \mathrm{mm}^{2}$. Approximately $80 \%$ of the media was replaced $24 \mathrm{hr}$ after plating, and cells were maintained for up to $7 \mathrm{~d}$ in a humidified atmosphere of $95 \% \mathrm{O}_{2}-5 \% \mathrm{CO}_{2}$ at $37^{\circ} \mathrm{C}$

Electrophysiological recordings. A coverslip carrying chromaffin cells was placed in a microperfusion chamber on the stage of an inverted phase-contrast microscope (Diaphot 200; Nikon, Tokyo, Japan). Cells were continuously superfused with an external solution consisting of (in $\mathrm{mM}$ ): $130 \mathrm{NaCl}, 2 \mathrm{KCl}, 1 \mathrm{MgCl}_{2}, 5 \mathrm{CaCl}_{2}, 10$ glucose, and $10 \mathrm{HEPES}$, adjusted to $\mathrm{pH} 7.2$ with $\mathrm{NaOH}$, osmolarity of $\sim 280 \mathrm{mOsm}$. In some experiments, cells were superfused with a external solution in which the $\mathrm{NaCl}$ was replaced with equimolar tetraethyl ammonium (TEA) chloride. Tetrodotoxin was omitted because it slows $\mathrm{Na}^{+}$channel-gating kinetics 10 -fold, resulting in a contamination of the $C_{\mathrm{m}}$ trace (Horrigan and Bookman, 1994). Drugs were prepared as stock solutions in doubledistilled water, except where stated, and then diluted at least 1000 -fold into external solution. Special care was taken to superfuse cells at a high rate $(\sim 3 \mathrm{ml} / \mathrm{min})$ throughout the experiment and to select well isolated single cells for recording to avoid compounding effects of endogenously released modulators (Carabelli et al., 1998).

Ionic currents were recorded in perforated patch-clamp configuration using borosilicate glass electrodes coated with Sylgard 184 (Dow Corning, Midland, MI) and fire polished on a microforge to a resistance of 1-2 $\mathrm{M} \Omega$. Electrodes were filled with an internal solution consisting of (in mM): 145 Cs-glutamate (Calbiochem, Nottingham, UK), 10 HEPES, 9.5 $\mathrm{NaCl}$, and 0.3 BAPTA (Molecular Probes, Eugene, OR), adjusted to $\mathrm{pH}$ 7.2 with $\mathrm{CsOH}$ (ICN Biomedicals, Aurora, OH), osmolarity $\sim 280$ mOsm. Gramicidin D (Sigma, Poole, UK) at a final concentration of 9.7 $\mu \mathrm{g} / \mathrm{ml}$ (stock solution in DMSO $1080 \mu \mathrm{g} / \mathrm{ml}$ ) was used for perforation. Flash photolysis experiments were performed as described by Parsons et al. (1996) using the whole-cell patch-clamp configuration and electrodes filled with an internal solution consisting of (in mM): 110 Cs-glutamate, 40 HEPES, 10 NP-EGTA (Molecular Probes), $7 \mathrm{CaCl}_{2}$, and 0.3 fura-2 pentapotassium salt (Calbiochem), adjusted to $\mathrm{pH} 7.2$ with $\mathrm{CsOH}$.

For both whole-cell and perforated patch recordings, series resistance was $<12 \mathrm{M} \Omega$ and compensated (typically $>70 \%$ ) electronically using a patch-clamp amplifier (Axopatch 200B; Axon Instruments, Foster City, CA). Voltage protocol generation and data acquisition were performed using custom data acquisition software (kindly provided by Dr. A. P. Fox, University of Chicago, Chicago, IL) running on a Pentium computer equipped with a Digidata 1200 acquisition board (Axon Instruments). Current traces were low-pass filtered at $5 \mathrm{kHz}$ using the four-pole Bessel filter supplied with the amplifier and digitized at $10 \mathrm{kHz}$. Current traces were corrected off-line for linear leakage current (typically $<10 \mathrm{pA}$, at $-90 \mathrm{mV}$ ) using the $\mathrm{P} 4$ method. Chromaffin cells were voltage-clamped at $-90 \mathrm{mV}$, and $C_{\mathrm{m}}$ was sampled with a resolution of $12 \mathrm{msec}$ using a software-based phase-tracking method as described previously (Fidler and Fernandez, 1989; Seward et al., 1995). $C_{\mathrm{m}}$ measurements were interrupted during voltage-steps and then resumed $40 \mathrm{msec}$ after the stimulus to exclude gating charge artifacts (Horrigan and Bookman, 1994; Chow et al., 1996). Data were stored on the computer hard drive and analyzed off-line using self-written analysis software (Axobasic;
Axon Instruments) and commercial software (Origin; Microcal, Northampton, MA). All experiments were performed at ambient temperature $\left(21-25^{\circ} \mathrm{C}\right)$.

Photolysis of caged calcium and $\left[\mathrm{Ca}^{2+}\right]_{i}$ measurements. Flashes of UV light were derived from a pulsed arc lamp (TILL Photonics, Planegg, Germany) coupled to the epi-illumination port of an Axiovert 100 inverted microscope equipped with a $40 \times$ oil immersion objective with a numerical aperture of 1.3 (Zeiss, Jena, Germany). UV flashes were restricted to a $240 \mu \mathrm{m}$ spot using the objective, and the cell under investigation was placed in the center of this region. Fluorescence measurements and UV flashes were restricted to the area immediately surrounding the cell using rectangular field stops. To measure $\left[\mathrm{Ca}^{2+}\right]_{\mathrm{i}}$, the internal solution contained fura-2 (for composition, see above), and the cell was alternately illuminated at 340 and $380 \mathrm{~nm}$ using a monochromator (TILL Photonics) controlled by the $C_{\mathrm{m}}$ data acquisition software. Emission $>430 \mathrm{~nm}$ was collected with a photomultiplier tube (TILL Photonics) and sampled at the rate of $C_{\mathrm{m}}$ measurements, approximately every $12 \mathrm{msec}$. Data were stored on a personal computer, and ratios of 340/380 nm were calculated off-line (Axobasic-written software). Calibration of fura-2 was performed by the method of Grynkiewicz et al. (1985). $R_{\min }$ and $R_{\max }$ were obtained by permeabilizing chromaffin cells with $10 \mu \mathrm{M}$ ionomycin or $3 \mu \mathrm{M}$ digitonin in the presence of $10 \mathrm{~mm}$ EGTA or $20 \mathrm{mM} \mathrm{Ca}^{2+}$, respectively. In control experiments $(n=4)$ in which cells were loaded with $\mathrm{Ca}^{2+}$-free NP-EGTA internal solution, flashes failed to produce either a rise in fura-2 ratio at $340 / 380 \mathrm{~nm}$ or $C_{\mathrm{m}}$.

In some perforated patch experiments, cells were loaded with the $\mathrm{Ca}^{2+}$ indicator by addition of $5 \mu \mathrm{M}$ fura-2 AM (Molecular Probes) to $\mathrm{DMEM}$ medium and incubating for $25 \mathrm{~min}$ at $37^{\circ} \mathrm{C}$. Cells were then washed with fresh DMEM and incubated an additional $15 \mathrm{~min}$ at $37^{\circ} \mathrm{C}$. The $K_{\mathrm{d}}$ for fura-2 alters according to the surrounding milieu (Grynkiewicz et al., 1985). Because the intracellular environment is unknown in the perforated patch configuration, coupled with difficulty in determining $R_{\text {min }}$, fura- 2 measurements were not calibrated in these experiments and ratios are given in Results.

Data analysis. $\Delta C_{\mathrm{m}}$ was measured relative to a $100 \mathrm{fF}$ calibration signal, which was routinely switched in and out of the circuit during the course of a recording. The $\Delta C_{\mathrm{m}}$ triggered by a single voltage pulse was calculated off-line. "Immediate" $\Delta C_{\mathrm{m}}$ occurring during a voltage pulse was measured by averaging four $C_{\mathrm{m}}$ points immediately before the voltage pulse and subtracting this value from the average of the first four $C_{\mathrm{m}}$ points acquired immediately after the voltage pulse. "Slow" $\Delta C_{\mathrm{m}}$ observed as drifts in $C_{\mathrm{m}}$ after membrane repolarization were measured by taking the average of the first four $C_{\mathrm{m}}$ points acquired immediately after the voltage pulse and subtracting them from the average of four $C_{\mathrm{m}}$ points taken at the peak of the $C_{\mathrm{m}}$ rise. Slow $\Delta C_{\mathrm{m}}$ that exceeded twice the resting $C_{\mathrm{m}}$ noise $(10-20 \mathrm{fF})$ were considered significant. Unless otherwise indicated, the total $\Delta C_{\mathrm{m}}$ resulting from a single depolarization was taken as the sum of the immediate response and slow response. The total $\Delta C_{\mathrm{m}}$ evoked by a train of depolarizations was calculated as the sum of immediate $\Delta C_{\mathrm{m}}$ for all the pulses in the train plus any drifts in $C_{\mathrm{m}}$ occurring between pulses. The latter was calculated by taking the average of the first four $C_{\mathrm{m}}$ points acquired after a pulse and subtracting them from the average of four $C_{\mathrm{m}}$ points taken before the next voltage pulse.

$\mathrm{Ca}^{2+}$ entry was determined by integration of $\mathrm{Ca}^{2+}$ currents $\left(I_{\mathrm{Ca}}\right)$, and the left limit was set $\sim 3 \mathrm{msec}$ into the voltage pulse, to exclude the major portion of the contaminating $\mathrm{Na}^{+}$current. Before integration, currents were leak-subtracted using the P4 method. Statistical significance was determined using either paired or independent Student's $t$ test, as appropriate. All data are expressed as the mean \pm SEM. Data reported are taken from 67 cells from 20 separate cultures.

\section{RESULTS}

Previous whole-cell patch-clamp studies with $\mathrm{Ba}^{2+}$ as the divalent cation have shown that ATP inhibits $I_{\mathrm{Ca}}$ in adrenal chromaffin cells (Diverse-Pierluissi et al., 1991; Gandia et al., 1993). For our studies on exocytosis, we used the perforated patch configuration to avoid secretory rundown (Engisch and Nowycky, 1996; Seward and Nowycky, 1996), and we used $\mathrm{Ca}^{2+}$ as the charge carrier to obtain efficient secretion (Seward et al., 1996). In non-neuronal cells and the chromaffin-like PC12 cell line, P2Y purinoceptors are commonly found to be $\mathrm{G}_{\mathrm{q}}$-coupled and reported to increase rather than decrease $\left[\mathrm{Ca}^{2+}\right]_{\mathrm{i}}$ (for review, see Boeynaems et al., 1998). Therefore, in our first series of experiments, we examined 
A
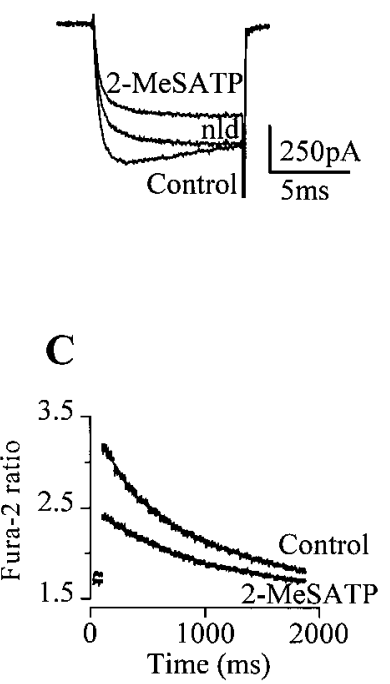

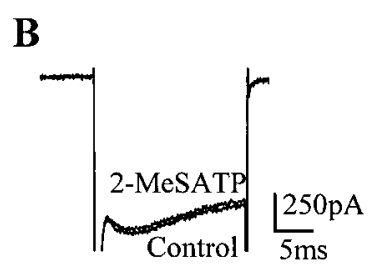

D

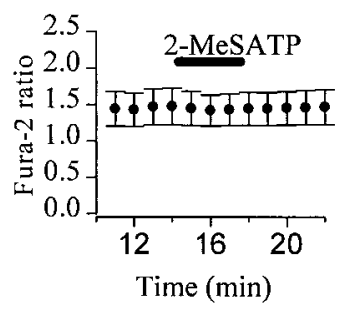

Figure 1. $\mathrm{P} 2 \mathrm{Y}$ receptor activation inhibited $I_{\mathrm{Ca}}$ in a voltage-dependent, PTX-sensitive manner. $A, B$, Superimposed current traces during a 20 msec depolarization to $+20 \mathrm{mV}$ from a holding potential of $-90 \mathrm{mV}$ in the absence (Control) or presence of $100 \mathrm{~nm}$ 2-MeSATP. $A, I_{\mathrm{Ca}}$ recorded after equimolar replacement of $\mathrm{NaCl}$ in the superfusing solution with TEA-Cl to remove contaminating $\mathrm{Na}^{+}$currents. Under control conditions, 2-MeSATP reduced the maximal current amplitude and slowed the activation kinetics. The effect on kinetics can be seen by normalizing the current in the presence of 2-MeSATP to the control trace $(n l d)$. $B$, Treatment with PTX (250 ng/ml, $24 \mathrm{hr}$ ) occluded the inhibitory effect of 2-MeSATP on $I_{\mathrm{Ca}}$. The transient current visible during the first $3 \mathrm{msec}$ of the depolarization is a $\mathrm{Na}^{+}$current, which has been cut off for illustration purposes only. $C, D$, Effect of 2-MeSATP on $\left[\mathrm{Ca}^{2+}\right]_{i}$ measured in cells loaded with the $\mathrm{Ca}^{2+}$ indicator fura-2 AM (see Materials and Methods). Data shown are the ratios of emitted fluorescence $(510 \mathrm{~nm})$ for excitation at 340 and $380 \mathrm{~nm}$. $C$, Measurement of cell-averaged $\left[\mathrm{Ca}^{2+}\right]_{i}$ recorded after a $30 \mathrm{msec}$ depolarization to $+20 \mathrm{mV}$ before (Control) and in the presence of 2-MeSATP. D, Superfusion of 2-MeSATP (100 nM) did not induce any changes in the resting $\left[\mathrm{Ca}^{2+}\right]_{\mathrm{i}}$ recorded at $-90 \mathrm{mV}$ immediately before a voltage step (data shown is the mean \pm SEM for $n=4$ ).

the effects of $\mathrm{P} 2 \mathrm{Y}$ purinoceptor activation on $\mathrm{Ca}^{2+}$ channels and $\left[\mathrm{Ca}^{2+}\right]_{\mathrm{i}}$ in isolated chromaffin cells under our recording conditions. Superfusion of 2-MeSATP, an ATP analog with preference for metabotropic purinoceptors, caused a reversible inhibition of $I_{\mathrm{Ca}}$ evoked by step depolarizations to $+20 \mathrm{mV}$ from a holding potential of $-90 \mathrm{mV}$ (Fig. $1 A$ ). The $\mathrm{IC}_{50}$ for 2-MeSATP inhibition of $I_{\mathrm{Ca}}$ was $\sim 3$ nм (A. D. Powell and E. P. Seward, unpublished observations). At a maximally effective concentration (100 nM), 2-MeSATP inhibited the $\mathrm{Ca}^{2+}$ entry integrated over 17 msec by $51 \pm 3 \%(n=5)$ and slowed current activation kinetics (Fig. 1A). Similar effects of 2-MeSATP were observed on $I_{\mathrm{Ca}}$ recorded using the whole-cell recording configuration in which $0.3 \mathrm{~mm}$ BAPTA was used to buffer $\left[\mathrm{Ca}^{2+}\right]_{\mathrm{i}}(47 \pm 2 \%$ inhibition; $n=4)$. The $I_{\mathrm{Ca}}$ inhibition was voltage-dependent because application of a $20 \mathrm{msec}$ prepulse to $+120 \mathrm{mV}$ reduced the inhibition of the integrated $\mathrm{Ca}^{2+}$ entry to $14 \pm 4 \%(n=3)$. Treatment of chromaffin cells with PTX $(250 \mathrm{ng} / \mathrm{ml}, 24 \mathrm{hr})$ reduced the effect of 2-MeSATP $(100 \mathrm{~nm})$ on integrated $\mathrm{Ca}^{2+}$ entry to $3.5 \pm 0.9 \%$ $(n=4)$ (Fig. $1 B)$. In cells loaded with fura-2 AM to monitor $\left[\mathrm{Ca}^{2+}\right]_{\mathrm{i}}$ under perforated patch recording conditions, superfusion with 2-MeSATP did not produce any significant change in basal $\left[\mathrm{Ca}^{2+}\right]_{\mathrm{i}}$ (mean ratio at $340 / 380 \mathrm{~nm}$ excitation before agonist was $1.48 \pm 0.24$ and in the presence of 2-MeSATP was $1.44 \pm$
$0.24 ; n=4)($ Fig. $1 D)$, suggesting that there are no functional $\mathrm{Ca}^{2+}$-mobilizing $\mathrm{G}_{\mathrm{q}}$-coupled $\mathrm{P} 2 \mathrm{Y}$ purinoceptors or $\mathrm{P} 2 \mathrm{X}$ purinoceptors. However, in these same cells, 2-MeSATP did inhibit peak stimulus-evoked $\left[\mathrm{Ca}^{2+}\right]_{\mathrm{i}}$ increases by $47 \pm 6 \%(n=4)$ (Fig. $1 C)$. Together, these data indicate that activation of purinoceptors in bovine adrenal chromaffin cells leads to inhibition of $\mathrm{Ca}^{2+}$ entry through $\mathrm{Ca}^{2+}$ channels and that this effect is mediated by a PTX-sensitive $\mathrm{G}_{\mathrm{i} / \mathrm{o}}$-protein.

\section{P2Y purinoceptor activation inhibits $\Delta C_{m}$ evoked by single long depolarizations}

Exocytosis in chromaffin cells and neurons is tightly regulated by $\mathrm{Ca}^{2+}$, with $\mathrm{Ca}^{2+}$ entry through $\mathrm{Ca}^{2+}$ channels providing the trigger for secretory vesicle fusion (Seward and Nowycky, 1996; Neher, 1998). Thus, we predicted that inhibition of $\mathrm{Ca}^{2+}$ channels by P2Y purinoceptors in chromaffin cells would be accompanied by a decrease in exocytosis. To measure exocytosis, we combined voltage-clamp recording of $\mathrm{Ca}^{2+}$ channels with $C_{\mathrm{m}}$ measurements to monitor vesicle fusion. Exocytosis was evoked by single long $(200 \mathrm{msec})$ depolarizations to $+20 \mathrm{mV}$ from a holding potential of $-90 \mathrm{mV}$ once every 3-5 min. Figure 2, $A$ and $C$, shows the time course and results of a typical experiment. Empirically, we found that this stimulus protocol produced reproducible stimulus-evoked $C_{\mathrm{m}}$ increases without the activitydependent changes in exocytotic efficiency (Fig. 2E) reported previously (Engisch et al., 1997; Smith, 1999). Before agonist application, the mean stimulus-evoked integrated $\mathrm{Ca}^{2+}$ entry over $197 \mathrm{msec}$ was $342 \pm 34 \times 10^{6}$ ions $(n=15)$. The resulting increases in $C_{\mathrm{m}}$ could be resolved into one or two kinetically distinct phases, depending on the cell. In all cells, $\mathrm{Ca}^{2+}$ entry was associated with an immediate increase in $\Delta C_{\mathrm{m}}$ with a mean secretory rate of $1430 \pm 190 \mathrm{fF} / \mathrm{sec}(n=15)$ (Fig. $2 D)$. In 6 of these 15 cells, the immediate $\Delta C_{\mathrm{m}}$ was followed by a smaller, slow $C_{\mathrm{m}}$ increase that had a mean rate of $204 \pm 56 \mathrm{fF} / \mathrm{sec}\left(\right.$ Fig. $\left.2 D_{2}\right)$. We found no correlation between the peak amplitude of the $I_{\mathrm{Ca}}$ or integrated $\mathrm{Ca}^{2+}$ entry and the presence or absence of slow $C_{\mathrm{m}}$ increases.

Superfusion with $100 \mathrm{~nm}$ 2-MeSATP produced a reversible inhibition of stimulus-evoked exocytosis (Fig. $2 C, D$ ). The inhibition of the immediate and slow $\Delta C_{\mathrm{m}}$ were, however, significantly different $(p=0.02)$ (Fig. $2 F)$. 2-MeSATP produced a mean inhibition of immediate $\Delta C_{\mathrm{m}}$ corresponding to $31 \pm 5 \%(n=15)$. The inhibition of $\mathrm{Ca}^{2+}$ entry integrated over $197 \mathrm{msec}$ was $22 \pm$ $3 \%$. In cells with pronounced slow exocytosis, 2-MeSATP inhibited the slow $\Delta C_{\mathrm{m}}$ by $52 \pm 6 \%(n=6)$. The larger inhibition of $\Delta C_{\mathrm{m}}$ compared with $\mathrm{Ca}^{2+}$ entry is consistent with the nonlinear $\mathrm{Ca}^{2+}$-dependence of exocytosis we (see Fig. $5 B$ ) and others have measured in chromaffin cells stimulated with long depolarizations (Engisch and Nowycky, 1996).

The inhibitory effects of $10 \mathrm{~nm} 2-\mathrm{MeSATP}$ on $\mathrm{Ca}^{2+}$ entry and $\Delta C_{\mathrm{m}}$ were less than those produced by $100 \mathrm{~nm}$, and they were reduced in the presence of the purinoceptor antagonist pyridoxalphosphate-6-azophenyl-2', $4^{\prime}$-disulphonic acid (100 $\mu \mathrm{M})$ from $16 \pm 3$ and $25 \pm 7 \%$ to $8 \pm 4$ and $11 \pm 2 \%$, respectively $(n=3)$.

\section{2-MeSATP inhibition of exocytosis involves $\mathbf{N}$ - and $\mathrm{P} / \mathrm{Q}$-type $\mathrm{Ca}^{2+}$ channels}

Release of neurotransmitter is often associated with specific subtypes of $\mathrm{Ca}^{2+}$ channels (Dunlap et al., 1995). In chromaffin cells, 

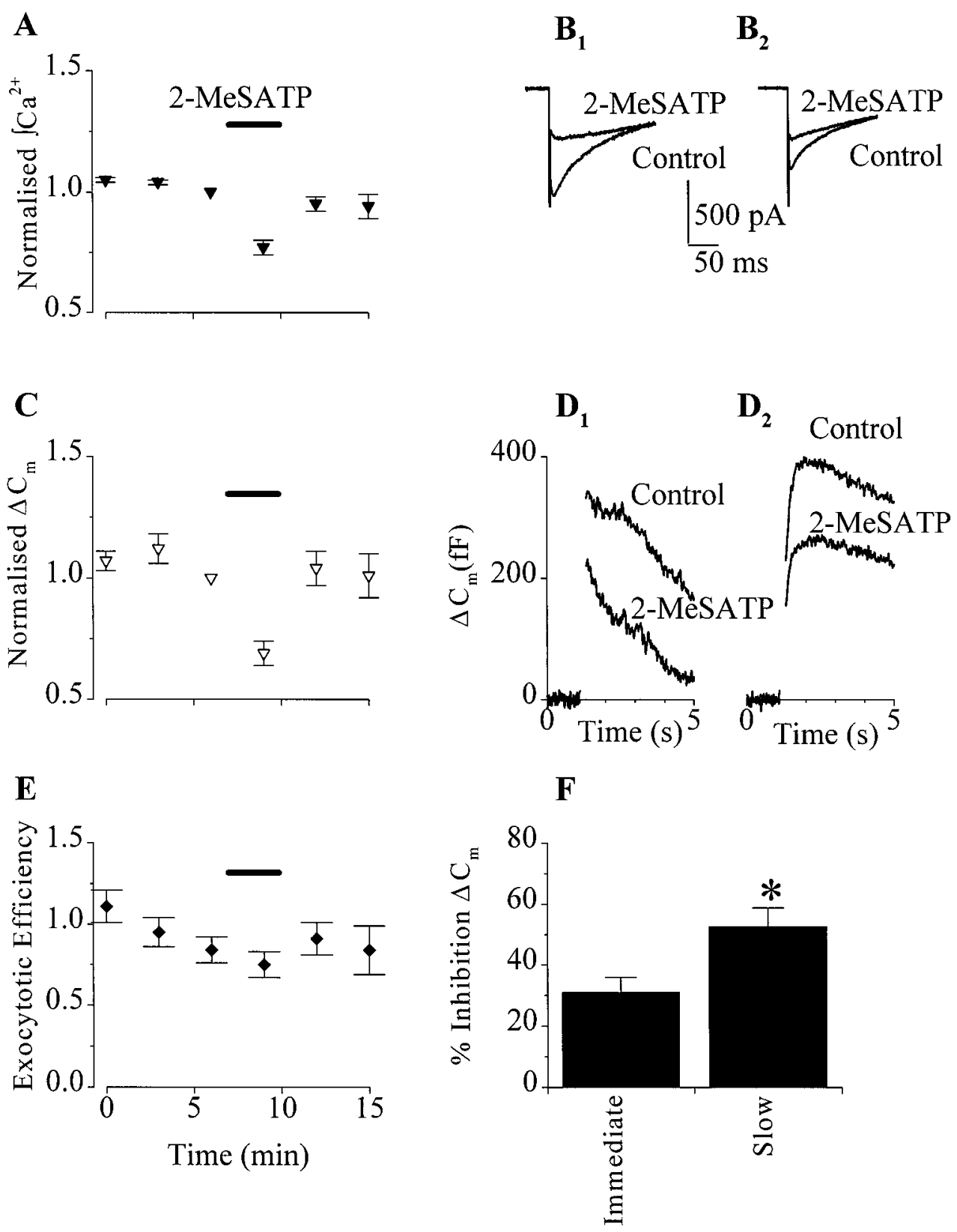

Figure 2. P2Y purinoceptor activation inhibited membrane capacitance $\left(C_{\mathrm{m}}\right)$ changes evoked by $200 \mathrm{msec}$ depolarizations. $A, C, E$, Diary plots of the effect of $100 \mathrm{~nm}$ 2-MeSATP on normalized $\mathrm{Ca}^{2+}$ entry as measured by integrating $I_{\mathrm{Ca}}(A)$, $\Delta C_{\mathrm{m}}(C)$, and exocytotic efficiency $\left(\Delta C_{\mathrm{m}} /\right.$ $\mathrm{Ca}^{2+}$ entry) $(E)$ (data plotted are the mean \pm SEM for $n=15$ ). Both integrated $\mathrm{Ca}^{2+}$ entry and $\Delta C_{\mathrm{m}}$ were normalized to the responses recorded immediately before 2-MeSATP application (horizontal bar). $B$, Superimposed currents recorded before (Control) and during superfusion with 2-MeSATP from two different chromaffin cells $\left(B_{1}\right.$ and $\left.B_{2}\right)$. Currents were evoked by a $200 \mathrm{msec}$ depolarization to $+20 \mathrm{mV}$ from $-90 \mathrm{mV} . D, \Delta C_{\mathrm{m}}$ recorded in response to currents shown in $B$. Gaps in the $C_{\mathrm{m}}$ traces represent when a voltage step was applied. Two kinetically distinct phases of $C_{\mathrm{m}}$ change were observed; in $D_{1}$, the response consisted solely of an immediate change in $C_{\mathrm{m}}$ and, in $D_{2}$, an additional slow component of exocytosis that appears as a drift up in $C_{\mathrm{m}}$ after the voltage step. 2-MeSATP inhibited both $I_{\mathrm{Ca}}$ $\left(B_{1}\right.$ and $\left.B_{2}\right)$ and the corresponding immediate and slow $\Delta C_{\mathrm{m}}\left(D_{1}\right.$ and $\left.D_{2}\right) . F$, Summary of the effect of 2-MeSATP on the immediate $(n=15)$ and slow $(n=6) \Delta C_{\mathrm{m}}$. $* p<0.02$ indicates significant difference between the effect of 2-MeSATP on immediate and slow $\Delta C_{\mathrm{m}}$. the role of pharmacologically distinct $\mathrm{Ca}^{2+}$ channels in exocytosis depends on stimulus conditions and development (Artalejo et al., 1994; Engisch and Nowycky, 1996; Lomax et al., 1997). We examined the role of different subtypes of $\mathrm{Ca}^{2+}$ channels in mediating the inhibitory effects of 2-MeSATP on exocytosis. Application of $\omega$-conotoxin GVIA ( $\omega$-CgTx GVIA) $(1 \mu \mathrm{M})$ to block $\mathrm{N}$-type $\mathrm{Ca}^{2+}$ channels inhibited $\mathrm{Ca}^{2+}$ entry by $29 \pm 5 \%$ and inhibited $\Delta C_{\mathrm{m}}$ evoked by single $200 \mathrm{msec}$ depolarizations by $34 \pm 5 \%(n=8)$ (Fig. $\left.3 B_{1}\right)$. Blockade of P/Q-type $\mathrm{Ca}^{2+}$ channels with $\omega$-agatoxin IVA ( $\omega$-Aga IVA) $(300 \mathrm{nM})$ inhibited $\mathrm{Ca}^{2+}$ entry by $52 \pm 9 \%$ and inhibited $\Delta C_{\mathrm{m}}$ by $73 \pm 9 \%(n=4)\left(\right.$ Fig. $\left.3 A, B_{1}\right)$. Combined application of $\omega$-CgTx GVIA and $\omega$-Aga IVA inhibited $\mathrm{Ca}^{2+}$ entry by $96 \pm 1 \%$ and inhibited $\Delta C_{\mathrm{m}}$ by $94 \pm 2 \%(n=$ 6) (Fig. $3 A$ ). No significant contributions to stimulus-evoked exocytosis from a dihydropyridine-sensitive "facilitation" channel were observed, presumably because our studies were performed on adult animals and $\mathrm{Ca}^{2+}$-dependent processes were not per- turbed by using barium as the charge carrier. We conclude therefore that, under our recording conditions, $\mathrm{Ca}^{2+}$ entry through $\mathrm{N}$ and P/Q-type channels triggers exocytosis. Furthermore, as observed with 2-MeSATP, the inhibition of secretion produced by either toxin was proportional to the inhibition of $\mathrm{Ca}^{2+}$ entry and did not alter the $\mathrm{Ca}^{2+}$-dependence of exocytosis.

To investigate the contribution of each subtype of $\mathrm{Ca}^{2+}$ channel to the modulation of secretion by 2-MeSATP, we applied $\omega$-CgTx GVIA $(1 \mu \mathrm{M})$ or $\omega$-Aga IVA (300 nM) alone to isolate $\mathrm{P} / \mathrm{Q}$ - or N-type $\mathrm{Ca}^{2+}$ channels, respectively. 2-MeSATP (100 nM) inhibited $\mathrm{Ca}^{2+}$ entry and $\Delta C_{\mathrm{m}}$ evoked by $\mathrm{N}$-type $\mathrm{Ca}^{2+}$ channels by $46 \pm 6$ and $44 \pm 7 \%(n=5)$ (Fig. $\left.3 A, B_{2}\right)$, whereas $\mathrm{Ca}^{2+}$ entry and $\Delta C_{\mathrm{m}}$ evoked by $\mathrm{P} / \mathrm{Q}$-type $\mathrm{Ca}^{2+}$ channels was inhibited by $18 \pm 9$ and $16 \pm 5 \%(n=4)$, respectively. The inhibitory effects of 2-MeSATP on $\mathrm{Ca}^{2+}$ entry and $\Delta C_{\mathrm{m}}$ involving $\mathrm{N}$-type channels was significantly greater than that involving $\mathrm{P} / \mathrm{Q}$-type channels $(p<0.05)$ (Fig. $\left.3 B_{2}\right)$. 


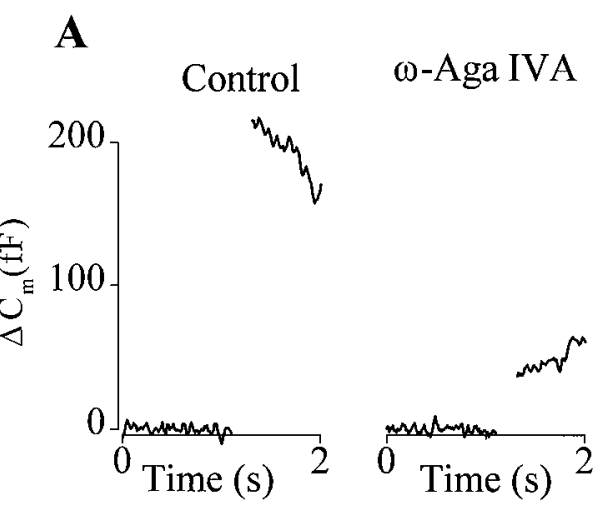

\author{
$\omega$-Aga IVA \\ \& 2-MeSATP
}

$\omega$-Aga IVA

$\& \omega-\mathrm{CgTx}$ GVIA

Figure 3. N- and P/Q-type $\mathrm{Ca}^{2+}$ channels mediated the inhibition of exocytosis by 2 -MeSATP. $A$, Data shown are from a single cell and illustrate the effect of $\omega$-Aga IVA (300 nm), 2-MeSATP (100 $\mathrm{nM})$, and $\omega$-CgTx GVIA $(1 \mu \mathrm{M})$ on both the $C_{\mathrm{m}}$ changes (top) and the associated $I_{\mathrm{Ca}}$ (bottom) recorded in response to 200 msec depolarization to $+20 \mathrm{mV}$ from a holding potential of $-90 \mathrm{mV}$. The voltage step is indicated by the gap in $C_{\mathrm{m}}$ trace. Both $C_{\mathrm{m}}$ changes and $I_{\mathrm{Ca}}$ were inhibited by $\omega$-Aga IVA ( $A$, second panel). The remaining $C_{\mathrm{m}}$ change and $I_{\mathrm{Ca}}$ were inhibited by 2-MeSATP ( $A$, third panel) and could be completely blocked by combined addition of $\omega$-Aga IVA and $\omega$-CgTx GVIA ( $A$, fourth panel). $B_{1}$, Summary of effects of the $\mathrm{Ca}^{2+}$ channel toxins $\omega$-CgTx GVIA $(n=8)$ and $\omega$-Aga IVA $(n=4)$ on integrated $\mathrm{Ca}^{2+}$ entry (open bars) and $\Delta C_{\mathrm{m}}$ (filled bars). $B_{2}$, Summary of the effect of 2-MeSATP on integrated $\mathrm{Ca}^{2+}$ entry (open bars) and $\Delta C_{\mathrm{m}}$ ( filled bars) evoked by isolated $\mathrm{Ca}^{2+}$ channel subtypes (N-type, $n=5$; P/Q-type, $n=$ 4). $\omega$-CgTx GVIA was used to isolate P/Q-type $\mathrm{Ca}^{2+}$ channels, and $\omega$-Aga IVA was used to isolate N-type $\mathrm{Ca}^{2+}$ channels. Similar results were obtained irrespective of the order in which the toxins were applied.
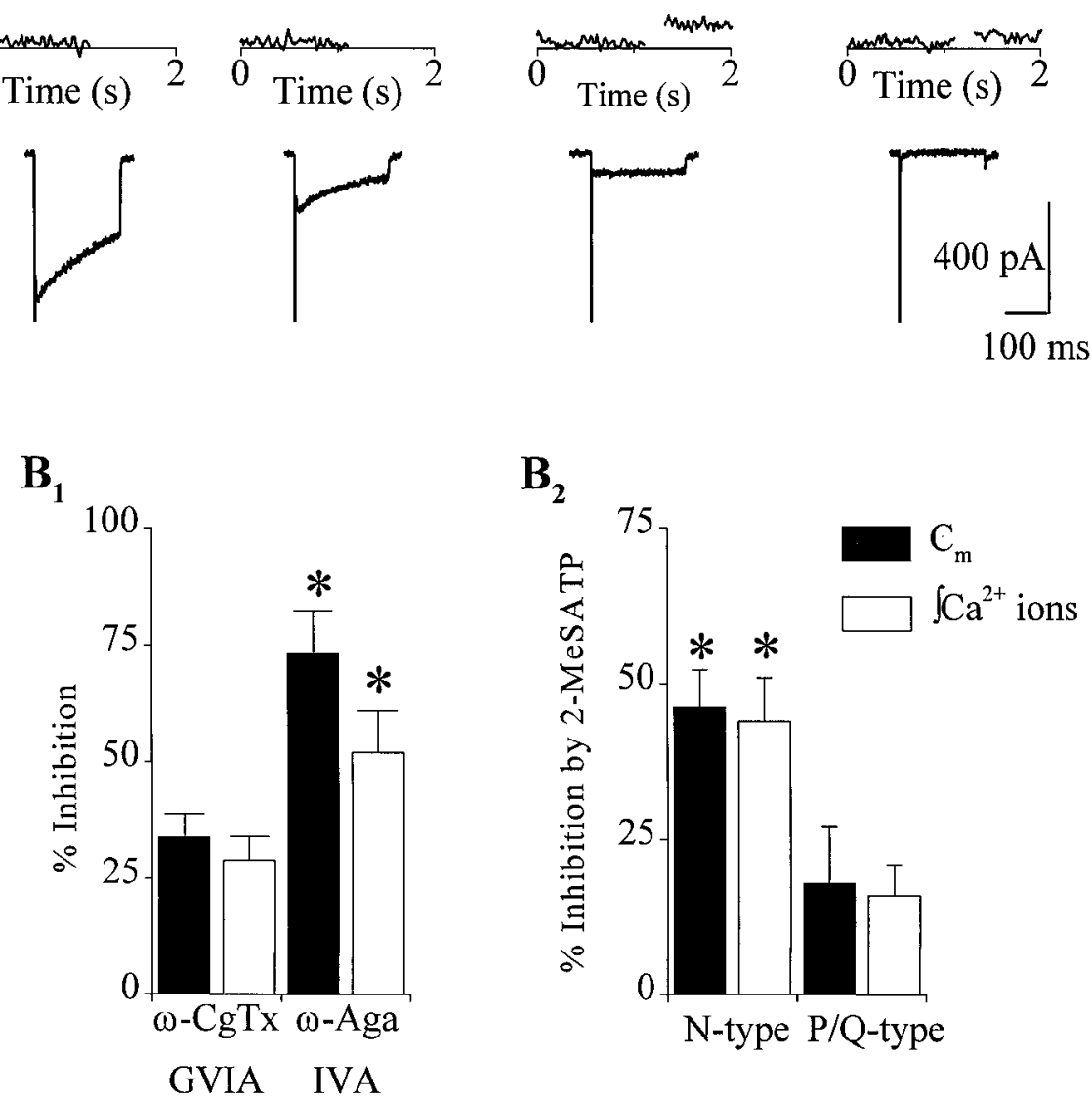

\title{
Strong depolarizing prepulses reverse 2-MeSATP inhibition of $\Delta C_{m}$
}

tional test pulse without a prepulse was given. The $\mathrm{Ca}^{2+}$ entry and $\Delta C_{\mathrm{m}}$ response to this second test pulse were inhibited by $16 \pm$ 3 and $31 \pm 7 \%$, respectively $(n=3)$. These experiments demonstrate that the inhibition of exocytosis by 2-MeSATP has the same voltage-dependence as inhibition of $\mathrm{Ca}^{2+}$ channels in adrenal chromaffin cells and support the hypothesis that the inhibition of $\Delta C_{\mathrm{m}}$ observed is caused by inhibition of $\mathrm{Ca}^{2+}$ entry.

thought to occur via "membrane-delimited" mechanism invo ing a direct interaction of $\mathrm{G}_{\beta \gamma}$ subunits with the $\mathrm{Ca}^{2+}$ channel $\alpha$ subunit (Dolphin, 1998). This interaction is voltage-dependent and can be relieved by strong depolarizing prepulses. We reasoned that, if 2-MeSATP inhibited exocytosis via inhibition of $\mathrm{Ca}^{2+}$ channels, then the inhibition of evoked $\Delta C_{\mathrm{m}}$ should also be attenuated by strong depolarizing prepulses. To test this, the test pulse used to evoke exocytosis was preceded by a $20 \mathrm{msec}$ depolarizing pulse to $+120 \mathrm{mV}$ (Fig. $4 A, B$ ). In the absence of the agonist, application of the prepulse had no significant effect on either $\Delta C_{\mathrm{m}}\left(98 \pm 1 \%\right.$ of control) or $\mathrm{Ca}^{2+}$ (98 $\pm 1 \%$ of control; $n=5$; data not shown) entry. In the presence of 2-MeSATP (100 $\mathrm{nM}$ ), a depolarizing prepulse, however, reduced the inhibition of both $\mathrm{Ca}^{2+}$ entry and $\Delta C_{\mathrm{m}}$ from $23 \pm 3$ and $35 \pm 4 \%$ to $10 \pm 2$ and $12 \pm 4 \%$, respectively $(n=9)$ (Fig. $4 C$ ). To show that the decreased inhibition by 2-MeSATP observed after a prepulse was not simply a result of receptor desensitization, in three of these cells, superfusion with 2-MeSATP was continued and an addi-

\section{P2Y purinoceptor activation does not alter the $\mathrm{Ca}^{2+}$ dependence of $\Delta C_{m}$}

To test further the hypothesis that inhibition of $\mathrm{Ca}^{2+}$ entry accounts for inhibition of $\Delta C_{\mathrm{m}}$, we examined the effect of increasing pulse duration on 2-MeSATP inhibition of stimulus-secretion coupling. During long depolarizations, agonist-dependent inhibition of $\mathrm{Ca}^{2+}$ channels is overcome (Dolphin, 1998), and therefore, an attenuation of the effects of 2-MeSATP on exocytosis are expected. The time-dependence of the modulation of $\Delta C_{\mathrm{m}}$ and $\mathrm{Ca}^{2+}$ entry by 2-MeSATP are shown in Figure $5, A$ and $B$. Increasing pulse duration from 20 to $400 \mathrm{msec}$ significantly reduced $(p<0.01)$ the inhibition of both $\Delta C_{\mathrm{m}}$ and $\mathrm{Ca}^{2+}$ entry from $67 \pm 11$ and $51 \pm 2 \%(n=5)$ to $14 \pm 4$ and $12 \pm 3 \%(n=$ 

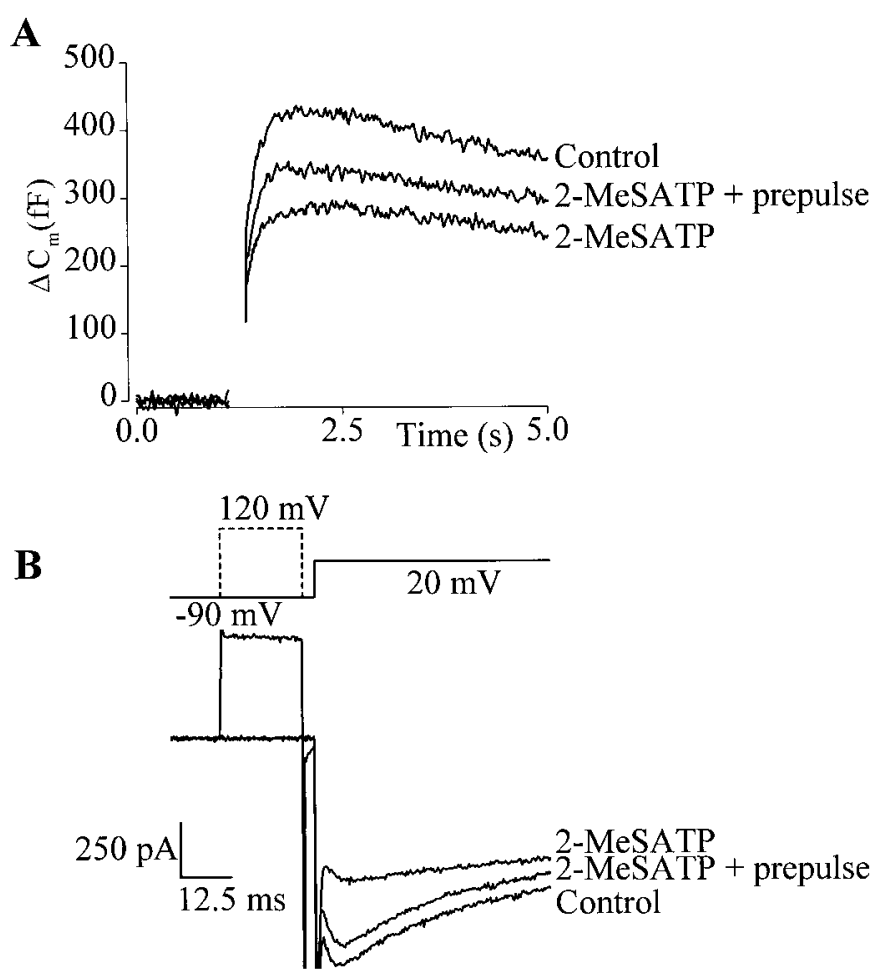

C

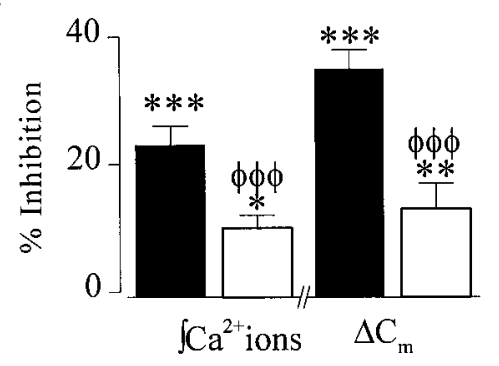

Figure 4. Modulation of both integrated $\mathrm{Ca}^{2+}$ entry and $\Delta C_{\mathrm{m}}$ was voltage-dependent. $A$, Superimposed traces from a single cell showing the effect of 2-MeSATP on $\Delta C_{\mathrm{m}}$ evoked by a $200 \mathrm{msec}$ depolarization to +20 $\mathrm{mV}$ from a holding potential of $-90 \mathrm{mV}$ with and without a $20 \mathrm{msec}$ depolarizing prepulse. $B$, Top, Schematic diagram of prepulse (hashed line) voltage protocol. $B$, Bottom, Superimposed $I_{\mathrm{Ca}}$ used to evoke $\Delta C_{\mathrm{m}}$ illustrated in $A$. Only the first $100 \mathrm{msec}$ of the $200 \mathrm{msec}$ test pulse are shown for clarity. $C$, Summary of the effects of 2-MeSATP on integrated $\mathrm{Ca}^{2+}$ entry and $\Delta C_{\mathrm{m}}$ in the presence (open bars) or absence (filled bars) of a depolarizing prepulse $(n=9)$. Significant effects of 2-MeSATP on $\mathrm{Ca}^{2+}$ entry and $C_{\mathrm{m}}$ relative to control are indicated: ${ }^{* * *} p<0.005 ;{ }^{* *} p<$ $0.01 ; * p<0.05$. Significant differences between responses recorded with and without a prepulse are indicated by ${ }^{\phi \phi \phi} p<0.005$.

4), respectively. Moreover, the small inhibition remaining with $400 \mathrm{msec}$ depolarization was reversed by depolarizing prepulses to $+120 \mathrm{mV}$ ( $n=4$; data not shown). The results from these experiments support the role of $\mathrm{Ca}^{2+}$ channels in agonistdependent inhibition of exocytosis.

Inhibition of exocytosis by a GPCR may also result from a direct decrease in the $\mathrm{Ca}^{2+}$ sensitivity of the secretory machinery or a decrease in the probability of release. The concomitant inhibition of $\Delta C_{\mathrm{m}}$ and $\mathrm{Ca}^{2+}$ entry, coupled with the lack of significant effect of 2-MeSATP on exocytotic efficiency (Fig. 2E), provide some evidence that the $\mathrm{Ca}^{2+}$ sensitivity of the secretory machinery was not changing. To test this further, we examined the $\mathrm{Ca}^{2+}$-dependence of $\Delta C_{\mathrm{m}}$ using the method described by
Engisch and Nowycky (1996). Exocytosis was evoked by single pulses of varying duration, first under control conditions and then in the presence of 2-MeSATP (100 nM) (Fig. 5A). The control data from 10 cells was plotted and fit with an allometric function $\Delta C_{\mathrm{m}}=g^{*}\left(\Delta \mathrm{Ca}^{2+}\right)^{n}$, and the best fit was obtained with a proportionality constant $g=0.0842$ and power $n=1.62$ (Fig. 5C). The power value obtained by fitting data from individual cells with the allometric function ranged from $n=1.01$ to 3.49, mean $n=1.68 \pm 0.29$. Similar variability and values for $n$ were reported by Engisch and Nowycky (1996). What accounts for this variability is at present unknown; however, it may involve differences in the amounts of endogenous $\mathrm{Ca}^{2+}$ buffers and size of the readily releasable pool of vesicles. Thus, in cells in which endogenous $\mathrm{Ca}^{2+}$ buffering is high, the relationship may be more linear because of a requirement to saturate the buffer before exocytosis can proceed. Similarly, in cells in which the size of the readily releasable pool of vesicles is small, the secretory response measured in response to long depolarizations may be dominated by release from the reserve pool. The $\mathrm{Ca}^{2+}$-dependence of vesicle recruitment from the reserve pool to the readily releasable pool is essentially linear (Neher, 1998). None the less, data obtained by varying $\mathrm{Ca}^{2+}$ entry by changing the step potential $(n=4)$ (Fig. $5 C$, open triangle) or application of $\mathrm{Ca}^{2+}$ channel toxins (data not shown) did not deviate from the allometric fit, demonstrating that the $\mathrm{Ca}^{2+}$-dependence of exocytosis was unaffected by simply reducing $\mathrm{Ca}^{2+}$ influx. Similarly, exocytosis evoked by 200 or 400 msec depolarizations in the presence of 2-MeSATP also overlays the control allometric fit (Fig. 5C, open circles). These experiments provided evidence that the inhibition of exocytosis observed with 2-MeSATP was not caused by a decrease in the $\mathrm{Ca}^{2+}$-dependence of exocytosis.

\section{2-MeSATP does not modulate exocytosis evoked by flash-released $\mathbf{C a}^{2+}$}

To determine whether 2-MeSATP inhibited the secretory machinery in chromaffin cells, we bypassed $\mathrm{Ca}^{2+}$ channels and used flash photolysis of caged $\mathrm{Ca}^{2+}$ to provide the trigger for exocytosis. We hypothesized that, if 2-MeSATP decreased either the $\mathrm{Ca}^{2+}$-dependence or the probability of release, then the rate of $\Delta C_{\mathrm{m}}$ evoked by photolyzed $\mathrm{Ca}^{2+}$ should also be decreased relative to control. In these experiments, we used NP-EGTA as the photolabile $\mathrm{Ca}^{2+}$ chelator because, in contrast to (1-(2-nitro-4,5dimethoxyphenyl)-1,2-diaminoethane- $N, N, N^{\prime}, N^{\prime}$-tetra-acetic; dimethoxynitrophenamine)-nitrophen, it did not produce a loading transient and produced smaller increases in $\left[\mathrm{Ca}^{2+}\right]_{\mathrm{i}}$, thus avoiding exocytosis of nonsecretory granules (Neher and Zucker, 1993; Parsons et al., 1996; Xu et al., 1998). Figure $6 A$ shows a typical whole-cell recording of $\Delta C_{\mathrm{m}}$ and $\left[\mathrm{Ca}^{2+}\right]_{\mathrm{i}}$ from a chromaffin cell loaded with NP-EGTA $\mathrm{Ca}^{2+}$ and fura-2. After 3 min of dialysis a UV flash was given to elevate $\left[\mathrm{Ca}^{2+}\right]_{\mathrm{i}}$, which produced a biphasic increase in $\Delta C_{\mathrm{m}}$ (Fig. $6 B$ ). Because the $\left[\mathrm{Ca}^{2+}\right]_{\mathrm{i}}$ could not be recorded during the flash, the estimated peak $\left[\mathrm{Ca}^{2+}\right]_{i}$ was calculated by fitting the decay of the fura- 2 signal with a monoexponential curve. The $\left[\mathrm{Ca}^{2+}\right]_{\mathrm{i}}$ evoked by a single flash measured by this method peaked at $3.7 \pm 1.2 \mu \mathrm{M}(n=12)$, well below the $100 \mu \mathrm{M}\left[\mathrm{Ca}^{2+}\right]_{\mathrm{i}}$ reported to evoke nonsecretory granule fusion (Xu et al., 1998). The mean exocytotic rate measured during $1 \mathrm{sec}$ immediately after the flash was $99 \pm 14 \mathrm{fF} / \mathrm{sec}(n=9)$, significantly less than the rate evoked by a single $200 \mathrm{msec}$ depolarization $(\sim 1000 \mathrm{fF} / \mathrm{sec})$. Previous studies have shown that the rate of secretion is proportional to $\left[\mathrm{Ca}^{2+}\right]_{\mathrm{i}}$ and the high exocytotic rates typically produced by depolarizations require $\left[\mathrm{Ca}^{2+}\right]_{\mathrm{i}}>50 \mu \mathrm{M}$ 
Figure 5. P2Y receptor activation did not affect the $\mathrm{Ca}^{2+}$-dependence of $C_{\mathrm{m}}$ changes evoked by long depolarizations. $A$, Superimposed traces show the effect of increasing voltage step duration on $I_{\mathrm{Ca}}$ (bottom) and corresponding $\Delta C_{\mathrm{m}}$ (top) in the absence and presence of 2-MeSATP $(\diamond) . B$, Plot of the inhibition of integrated $\mathrm{Ca}^{2+}$ entry ( $\left.\square\right)$ and $\Delta C_{\mathrm{m}}(\mathbf{\square})$ by 2-MeSATP, for $20(n=5), 50(n=5), 200$ $(n=15)$, and $400(n=4)$ msec step depolarizations to $+20 \mathrm{mV}$. A significant reduction of the effect of 2-MeSATP on integrated $\mathrm{Ca}^{2+}$ entry and $\Delta C_{\mathrm{m}}$ evoked by longer depolarizations relative to 20 msec are indicated: ${ }^{* *} p<0.01 ;{ }^{*} p<0.05$. $C$, Plot of mean $\Delta C_{\mathrm{m}}$ versus mean integrated $\mathrm{Ca}^{2+}$ entry for 10 experiments similar to that illustrated in $A$. $\mathbf{\Delta}$, Data obtained under control conditions with voltage steps to $+20 \mathrm{mV}$ of varied durations. Data were binned according to pulse duration (7.5-500 msec). Horizontal error bars represent the SEM of the integrated $\mathrm{Ca}^{2+}$ entry for a given pulse duration. $\bigcirc$, Data obtained with 200 and 400 msec voltage steps to $+20 \mathrm{mV}$ (arrows) in the absence and presence of $100 \mathrm{nM}$ 2-MeSATP. $\nabla$, Data obtained under control conditions but with $200 \mathrm{msec}$ depolarizations to $0 \mathrm{mV}$. The $\mathrm{Ca}^{2+}$-dependence of $\Delta C_{\mathrm{m}}$ was calculated according to the method of Engisch and Nowycky (1996). Mean control data were fit to the equation $\Delta C_{\mathrm{m}}=\mathrm{g}^{*}\left(\Delta \mathrm{Ca}^{2+}\right)^{n} ;$ the solid line through the data represents the best fit with proportionality constant $g=0.08$ and the power $n=1.62$. $\Delta C_{\mathrm{m}}$ recorded in the presence of 2-MeSATP did not significantly deviate from the control $\mathrm{Ca}^{2+}$. dependence curve.
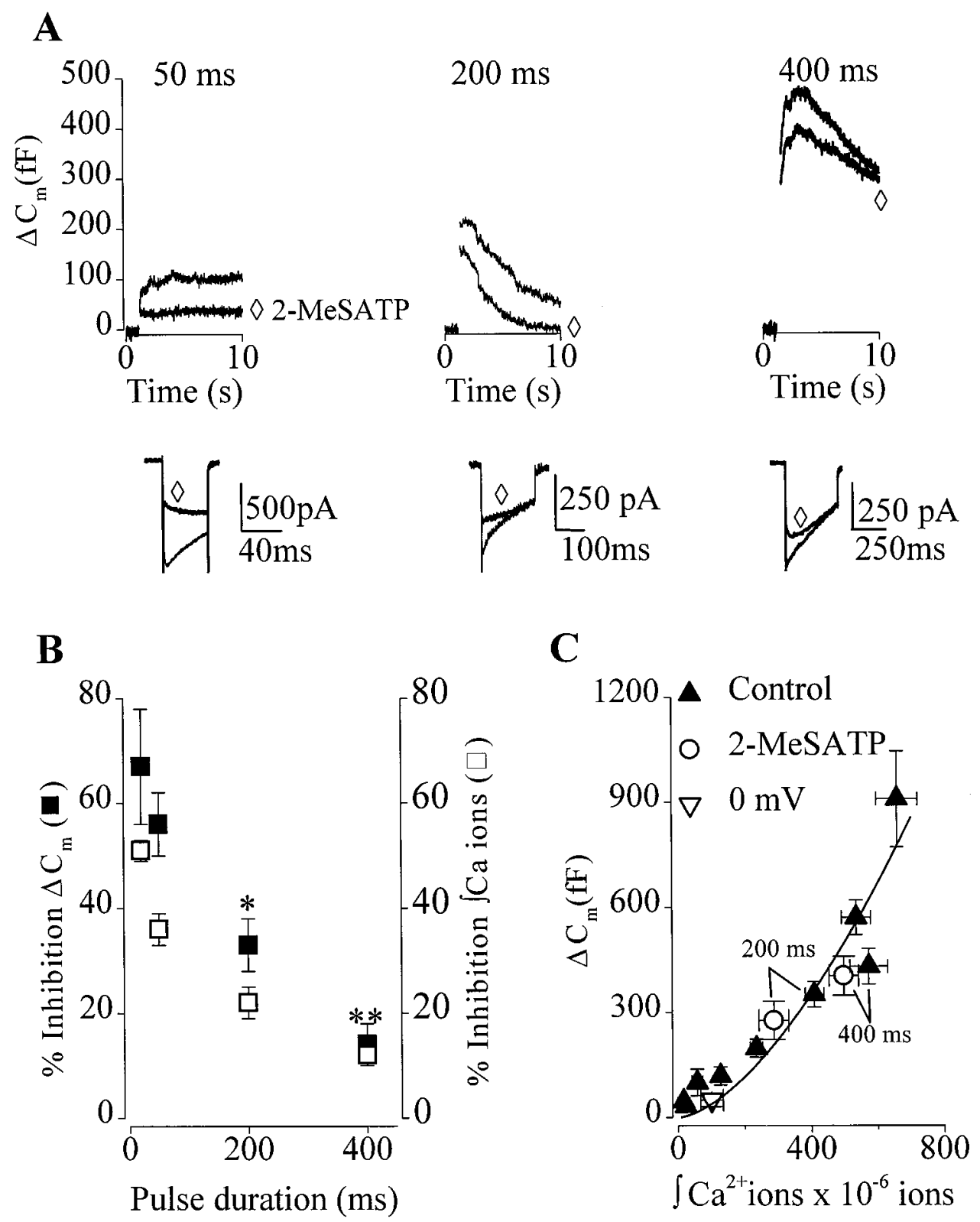

(Neher and Zucker, 1993). Thus, the relatively slow secretory rates observed with photoreleased $\mathrm{Ca}^{2+}$ in our studies are consistent with the small increases in $\left[\mathrm{Ca}^{2+}\right]_{\mathrm{i}}$ measured $(\sim 4 \mu \mathrm{M})$ and are in good agreement with the rates obtained by Heinemann et al. (1994).

Under control conditions, we observed rapid secretory rundown such that subsequent flashes failed to produce reproducible $\Delta C_{\mathrm{m}}$, despite comparable increases in $\left[\mathrm{Ca}^{2+}\right]_{\mathrm{i}}($ Fig. $6 A)$, suggesting that refilling of the readily releasable pool was impaired in whole-cell recording (see also Seward and Nowycky, 1996). This prevented the examination of the effects of $\mathrm{P} 2 \mathrm{Y}$ purinoceptor activation on flash-evoked $\Delta C_{\mathrm{m}}$ within a single cell. Therefore, we compared secretory rates recorded from matched (same culture) control cells and cells superfused with $100 \mathrm{~nm}$ 2-MeSATP for 2 min before the first UV flash. 2-MeSATP did not significantly affect the rates (Fig. $6 B$ ), nor did it inhibit the extent of $\Delta C_{\mathrm{m}}$ (control, $194 \pm 56 \mathrm{fF}, n=6$; 2-MeSATP, $140 \pm 49 \mathrm{fF}, n=4$ ) evoked by photolysis of NP-EGTA, providing further evidence against a direct inhibitory action of P2Y purinoceptors on the secretory machinery of chromaffin cells.

\section{2-MeSATP acts through $\mathrm{G}_{\mathrm{i} / \mathrm{o}}$-proteins to inhibit $\Delta \boldsymbol{C}_{\mathrm{m}}$ evoked by a train of depolarizing pulses}

In situ chromaffin cells secrete catecholamines, ATP, and peptides most efficiently in response to splanchnic nerve stimulation and bursts of action potentials (Douglas and Poisner, 1966; Edwards et al., 1980). To determine whether P2Y receptor activation inhibited exocytosis evoked by bursts of action potentials, we examined the effects of 2-MeSATP on $\Delta C_{\mathrm{m}}$ evoked by trains of short-duration depolarizations. A control train of 20 depolarizations of $20 \mathrm{msec}$ duration given at $2.5 \mathrm{~Hz}$ evoked entry of $541 \pm$ $42 \times 10^{6} \mathrm{Ca}^{2+}$ ions and $\Delta C_{\mathrm{m}}$ of $265 \pm 31 \mathrm{fF}$ in total, and an overall mean exocytotic efficiency of $0.64 \pm 0.2 \mathrm{fF} / 10^{6} \mathrm{Ca}^{2+}$ ions. Similar responses were evoked by subsequent control trains of depolarizations (mean exocytotic efficiency $0.52 \pm 0.7 \mathrm{fF} / 10^{6}$ $\mathrm{Ca}^{2+}$ ions; $n=23 ; p=0.92$ ), showing that exocytosis did not 

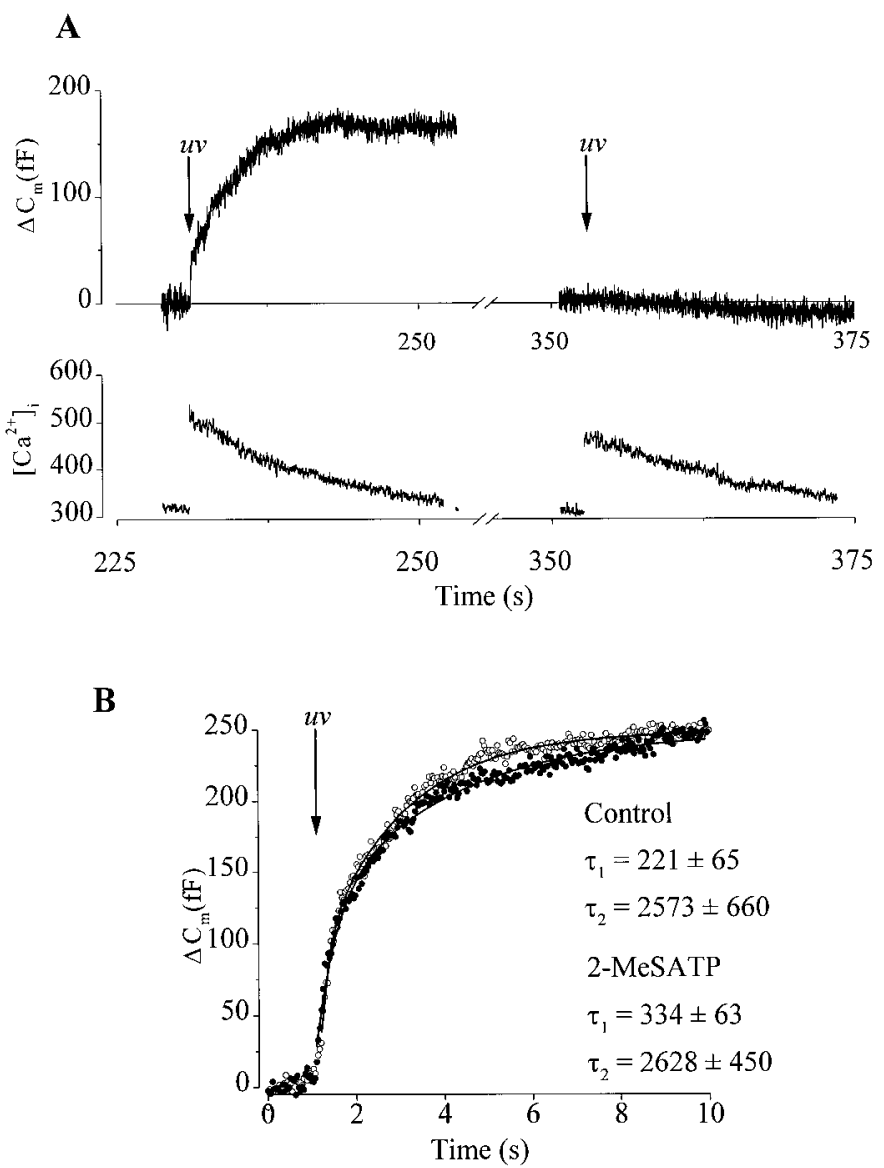

Figure 6. P2Y receptor activation did not modulate secretion evoked by flash photolysis of caged $\mathrm{Ca}^{2+} . A, C_{\mathrm{m}}$ traces (top trace) and corresponding $\left[\mathrm{Ca}^{2+}\right]_{\mathrm{i}}$ (bottom trace) recorded in response to the first flash $(80 \mathrm{~J}, 500$ $\mu \mathrm{sec}$ ) given $\sim 240 \mathrm{sec}$ after establishing the whole-cell configuration (left panel) and a second flash of the same intensity given $120 \mathrm{sec}$ later to the same cell (right panel). $B$, Kinetic analysis of two example $\Delta C_{\mathrm{m}}$ recorded in response to the first flash after establishing the whole-cell configuration, either under control conditions $(\bigcirc)$ or in the presence of $100 \mathrm{nM}$ 2-MeSATP $(\bullet)$. For clarity of illustration, only every third point is shown. The solid line drawn through the data represents a double-exponential fit obtained using the $C_{\mathrm{m}}$ point immediately after the UV flash and the plateau level as limits. The mean time constants displayed are for both control conditions $(n=5)$ and in the presence of 100 nM 2-MeSATP $(n=4)$.

undergo activity-dependent changes with these relatively mild stimuli (Engisch et al., 1997; Smith, 1999). Both the $\Delta C_{\mathrm{m}}$ and $\mathrm{Ca}^{2+}$ entry in response to a train of depolarizations were significantly inhibited by $100 \mathrm{~nm}$ 2-MeSATP (Fig. 7A,B); thus, total $\mathrm{Ca}^{2+}$ entry was reduced to $435 \pm 34 \times 10^{6} \mathrm{Ca}^{2+}$ ions and total $\Delta C_{\mathrm{m}}$ to $222 \pm 31 \mathrm{fF}(n=23)$. Inhibition of $\mathrm{Ca}^{2+}$ entry and $\Delta C_{\mathrm{m}}$ were, however, more pronounced early in the train, reaching a maximum of $54 \pm 6 \%$ on the fourth pulse and a minimum of $18 \pm$ $5 \%$ on the 20th pulse $(n=23)$ (Fig. $7 B)$.

Neither the exocytotic efficiency $\left(0.51 \pm 0.6 \mathrm{fF} / 10^{6} \mathrm{Ca}^{2+}\right.$ ions; $p=0.98)$ nor the $\mathrm{Ca}^{2+}$-dependence of secretion evoked by trains of depolarizations was altered by 2-MeSATP (Fig. $7 C$ ), suggesting that the mechanisms involved in inhibition of secretion evoked by single long pulses or trains of depolarizations are similar. We next examined the voltage-dependence of the inhibition by giving a 20 msec depolarizing prepulse to $+120 \mathrm{mV}$ before every test pulse in the train. In the absence of depolarizing prepulses, 2-MeSATP inhibited both $\mathrm{Ca}^{2+}$ entry and $\Delta C_{\mathrm{m}}$ by $35 \pm 4$ and $45 \pm 8 \%$,

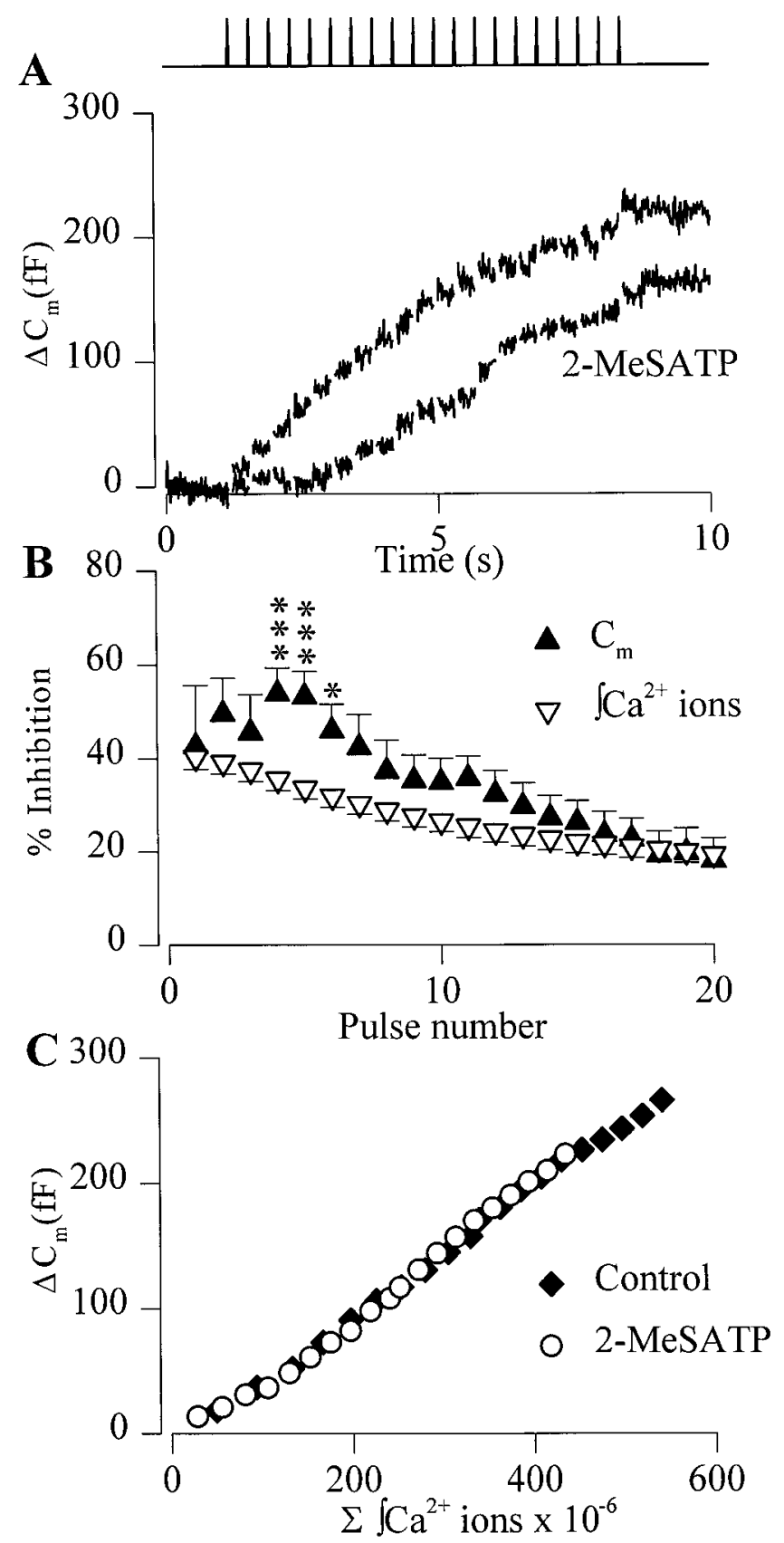

Figure 7. $\mathrm{P} 2 \mathrm{Y}$ receptor activation inhibited $\Delta C_{\mathrm{m}}$ evoked by a train of depolarizing pulses. $A$, Superimposed $C_{\mathrm{m}}$ traces recorded from a single cell in response to a train of twenty $20 \mathrm{msec}$ depolarizing pulses to $+20 \mathrm{mV}$ from $-90 \mathrm{mV}$. A control train (top trace) evoked an appreciable change in $C_{\mathrm{m}}$, and superfusion of 2-MeSATP (bottom trace) inhibited the $\Delta C_{\mathrm{m}}$ in response to a subsequent train. Gaps in the traces and schematic in the top panel indicate timing of the pulses. $B$, Summary of the mean \pm SEM inhibition of integrated $\mathrm{Ca}^{2+}$ entry $(\nabla)$ and $\Delta C_{\mathrm{m}}(\mathbf{\Delta})$ by 2-MeSATP for each pulse in the train of depolarizations. Significant differences between inhibition of integrated $\mathrm{Ca}^{2+}$ entry and $\Delta C_{\mathrm{m}}$ changes are shown: ${ }^{* * *} p<$ $0.005 ;{ }^{*} p<0.05(n=23)$. $C$, Plot of the mean $\mathrm{Ca}^{2+}$-dependence of $\Delta C_{\mathrm{m}}$ measured in response to a train of depolarizing pulses in the absence $(\bullet)$ and presence $(\bigcirc)$ of 2-MeSATP $(n=23)$. Error bars are omitted for clarity.

respectively (mean inhibition for pulses four to eight of a train, $n=$ 4). In the same cells, a depolarizing prepulse preceding each test pulse reduced the inhibitory effect of 2-MeSATP on $\mathrm{Ca}^{2+}$ entry to $-2 \pm 4 \%$ and $\Delta C_{\mathrm{m}}$ to $-17 \pm 12 \%$. Finally, we examined the 
second messenger system mediating the inhibitory effects of 2-MeSATP on stimulus-secretion coupling in chromaffin cells. Pretreatment with PTX (250 ng/ml, $24 \mathrm{hr}$ ) reduced the inhibitory effect of 2-MeSATP (100 nM) on $\mathrm{Ca}^{2+}$ entry to $-2 \pm 2.5 \%$ and $\Delta C_{\mathrm{m}}$ to $-8 \pm 14 \%(n=4)$. Collectively, these data show that 2-MeSATP inhibition of exocytosis evoked by single or trains of depolarizations was mediated by a $\mathrm{G}_{\mathrm{i} / \mathrm{o}}$-coupled $\mathrm{P} 2 \mathrm{Y}$ purinoceptor modulating $\mathrm{Ca}^{2+}$ entry through $\mathrm{Ca}^{2+}$ channels.

\section{DISCUSSION}

Given the ubiquity of ATP in secretory vesicles (Zimmermann, 1994) and the profusion of $P 2$ purinoceptors in the nervous system (North and Barnard, 1997), the potential for ATP to play a major modulatory role in neurotransmission is high. In the sympathetic nervous system, the inhibitory effects of presynaptic purinoceptors on neurotransmission have been well documented (Von Kügelgen et al., 1989; Boehm, 1999). A lack of selective agonists and antagonists, coupled with the inaccessibility of the majority of mammalian nerve terminals, have, however, made investigation of the mechanisms underlying inhibition of transmitter release by ATP difficult. In this study, we have used combined voltage-clamp recording and $C_{\mathrm{m}}$ measurements to investigate the effects of purinoceptors on exocytosis in adrenal chromaffin cells. The results show that 2-MeSATP, a potent agonist at $\mathrm{P} 2 \mathrm{Y}$ purinoceptors, inhibited exocytosis through an effect on $\mathrm{N}$ - and $\mathrm{P} / \mathrm{Q}$-type $\mathrm{Ca}^{2+}$ channels. The inhibition of stimulus-secretion coupling was mediated by $\mathrm{G}_{\mathrm{i} / \mathrm{o}}$-proteins and was voltage-dependent. Activation of P2Y purinoceptors had no effects downstream of $\mathrm{Ca}^{2+}$ entry on the secretory machinery. The results of this study strongly support the hypothesis that inhibition of presynaptic $\mathrm{Ca}^{2+}$ channels plays the major role in presynaptic inhibition of elicited neurotransmitter release by $G_{i}$ / oPCRs (Wu and Saggau, 1997) and that this is the mechanism underlying negative feedback modulation of sympathetic transmitter release by $\mathrm{P} 2 \mathrm{Y}$ purinoceptors.

Inhibition of neuronal $\mathrm{Ca}^{2+}$ channels by GPCR is thought to represent a ubiquitous mode of modulation of neuronal function (Hille, 1994). The most widely studied and best understood pathway is a membrane-delimited pathway involving a direct interaction of $\mathrm{G}_{\beta \gamma}$ subunits with the $\mathrm{Ca}^{2+}$ channel pore-forming $\alpha_{1}$ subunit (Page et al., 1998; Jeong and Ikeda, 1999). A characteristic property of this signaling pathway is its voltage-dependence in that the inhibition is relieved by strong depolarizations (Dolphin, 1998). In agreement with previous studies in chromaffin cells (DiversePierluissi et al., 1991; Currie and Fox, 1996), we show that P2Y purinoceptors inhibit $\mathrm{N}$ - and $\mathrm{P} / \mathrm{Q}$-type $\mathrm{Ca}^{2+}$ channels by a PTXsensitive, voltage-dependent pathway, strongly suggesting that the membrane-delimited pathway is involved (Figs. 1, 3, 4). A functional link between the P2Y-mediated suppression of evoked $I_{\mathrm{Ca}}$ and secretion is shown by the inhibition of evoked $\Delta C_{\mathrm{m}}$ (Figs. 2, 3, 6). In agreement with previous studies (Currie and Fox, 1997; Zamponi and Snutch, 1998), we also find a greater inhibition of $\mathrm{Ca}^{2+}$ entry through $\mathrm{N}$-type over $\mathrm{P} / \mathrm{Q}$-type channels, and this is paralleled by a greater inhibition of secretion supported by $\mathrm{N}$-type channels. Paradoxically, we found that N-type channels contributed less than $\mathrm{P} / \mathrm{Q}$-type channels to secretion evoked by long depolarizations. The lower sensitivity of P/Q-type channels to modulation by 2-MeSATP suggests either a lower efficacy of interaction between $\mathrm{G}_{\mathrm{i} / \mathrm{o}}$-proteins and $\mathrm{P}$ - and/or Q-type channels (Bourinet et al., 1999) or preferential compartmentalization of P2Y purinoceptors with N-type channels (Carabelli et al., 1998). Such differential coupling between a GPCR and exocytosis will have significant functional consequences in neurons in which there is tight coupling between subtypes of $\mathrm{Ca}^{2+}$ channels and transmitter release (for review, see Caterall, 1999) and could provide a mechanism whereby cotransmitters stored in separate pools of vesicles may be independently modulated (Von Kügelgen, 1996).

The results from this study demonstrate that the inhibition of exocytosis by a $\mathrm{G}_{\mathrm{i} / \mathrm{o}}$ PCR can be fully accounted for by the inhibition of $\mathrm{Ca}^{2+}$ channels. Three lines of evidence support this hypothesis. First, the $\mathrm{Ca}^{2+}$-dependence of secretion for both stimulus parameters is unaffected by activation of P2Y purinoceptors (Figs. 5, 7). Second, strong depolarizing prepulses relieve the voltage-dependent inhibition of $\mathrm{Ca}^{2+}$ channels by 2-MeSATP and, in parallel, the inhibition of exocytosis (Fig. 4). We do not believe that the voltagedependent relief of secretory inhibition observed in chromaffin cells is caused by a $\mathrm{Ca}^{2+}$-independent, voltage-dependent enhancement of exocytosis similar to that described for fast neurotransmitter systems (Linial et al., 1997; Mochida et al., 1998) because, under our control conditions, strong depolarizing prepulses did not enhance $\Delta C_{\mathrm{m}}$ per se. The final piece of evidence for the lack of effect of $\mathrm{P} 2 \mathrm{Y}$ purinoceptor activation on the secretory machinery comes from the flash photolysis experiments in which exocytosis was evoked independently of $\mathrm{Ca}^{2+}$ channels (Fig. 6). Our data contradicts conclusions from a previous study in which it was suggested that ATP can inhibit the exocytotic machinery in chromaffin cells (Lim et al., 1997). The discrepancy between the two studies may arise from either differences between signaling systems of chromaffin cells from two species or differences in the methods used. Lim and coworkers (1997) used the whole-cell patch-clamp recording technique and examined the rates of exocytosis after slow infusion of buffered $\mathrm{Ca}^{2+}$ solutions into the cells. Differences in chromaffin cell secretory properties have been reported with secretory rundown, complicating data interpretation (von Ruden and Neher, 1993; Seward et al., 1995; Engisch and Nowycky, 1996). Interestingly, the results from our study are in close agreement with results from a central synapse (Takahashi et al., 1996) and peptidergic terminals (Rusin et al., 1997), suggesting that G-protein regulation of voltage-operated $\mathrm{Ca}^{2+}$ channels is the predominant mechanisms underlying presynaptic inhibition of evoked release.

Exocytosis evoked by long depolarizations in chromaffin cells consists of two kinetically distinct components, referred to as immediate and slow exocytosis (Horrigan and Bookman, 1994). P2Y purinoceptor activation inhibited the slow phase of exocytosis to a significantly greater extent than the immediate phase (Fig. 2). A similar observation has been previously reported for opioid inhibition of exocytosis in the neurohypophysis (Rusin et al., 1997). The two kinetically distinct phases of exocytosis are thought to represent release of vesicles with varying degrees of readiness depending on their location in the secretory pathway; thus, immediate exocytosis is caused by fusion of readily releasable vesicles docked to $\mathrm{Ca}^{2+}$ channels, and slow release is caused by fusion of readily releasable vesicles responding to diff used $\mathrm{Ca}^{2+}$ (Thomas et al., 1990; Horrigan and Bookman, 1994; Chow et al., 1996; Seward and Nowycky, 1996). Alternatively, slow release may represent exocytosis of vesicles from the reserve pool, which are also regulated by diffused $\mathrm{Ca}^{2+}$. Release evoked by diffused $\mathrm{Ca}^{2+}$ is expected to involve multiple subtypes of $\mathrm{Ca}^{2+}$ channels and their associated $\mathrm{G}_{\mathrm{i} / \mathrm{o}}$-proteins, and therefore, consistent with our results, the inhibition of slow release should be correlated to the inhibition of the total $\mathrm{Ca}^{2+}$ entry. On the other hand, if immediate $\Delta C_{\mathrm{m}}$ are associated with chromaffin granules preferentially colocalized with a subtype of $\mathrm{Ca}^{2+}$ channel, then modulation of immediate secretion would depend on the 
efficacy of coupling between $\mathrm{G}_{\mathrm{i} / \mathrm{o}}$-proteins and that particular channel subtype. The relatively small inhibition of immediate exocytosis observed with 2-MeSATP more closely matches the inhibition of $\mathrm{P} / \mathrm{Q}$-type than $\mathrm{N}$-type $\mathrm{Ca}^{2+}$ channels, which would be expected if granules are preferentially docked to $\mathrm{P} / \mathrm{Q}$-type channels. Support of granule docking to P/Q-type channels comes from a previous study (Lara et al., 1998), as well as our own observations that $\omega$-Aga IVA is a more potent inhibitor of exocytosis than $\omega$-CgTx GVIA. Alternatively, a reduced effectiveness of P2Y purinoceptors to inhibit immediate exocytosis may result from saturation of the $\mathrm{Ca}^{2+}$ sensor (Rusin et al., 1997). We do not believe this to be the case because, if the fusion machinery were saturated then at short depolarizations in which release occurs predominantly from the readily releasable pool, the inhibition of secretion by 2-MeSATP should be occluded. This was not observed; indeed, inhibition was greatest with short depolarizations (Fig. 5B). Although the mechanisms underlying the reduced inhibition of immediate release require further investigation, a consequence of this phenomenon will be that, in vivo, released ATP would be more effective at inhibiting asynchronous release than synchronous release and thus would serve to maintain a tight temporal correlation between action potential firing and evoked transmitter release.

Catecholamine secretion from chromaffin cells is most efficiently triggered by high-frequency stimulation of the splanchnic nerve and bursts of action potentials (Edwards, 1982; Zhou and Misler, 1995). We found that P2Y modulation of secretion declines during a train of short depolarizations such that $\sim 50 \%$ of the modulatory effect remains at the end of a train. There are two possible explanations for the loss of effect. First, this study (Fig. $7 B$ ) and other studies (Seward et al., 1995; Engisch and Nowycky, 1996) show that significant inactivation of $\mathrm{Ca}^{2+}$ channels occurs during a train of depolarizations. It is possible that the loss of modulatory effect is caused by inactivation of the $\mathrm{Ca}^{2+}$ channels modulated by 2-MeSATP. Alternatively, recent studies have shown that voltage-dependent modulation of $\mathrm{Ca}^{2+}$ channels by $\mathrm{G}_{\beta \gamma}$ subunit is strongly dependent on the frequency at which the channels are activated, with high-frequency trains reversing inhibition (Brody et al., 1997; Park and Dunlap, 1998). It seems unlikely, however, that this is occurring in our experiments because reinhibition of $\mathrm{N}$ - and $\mathrm{P} / \mathrm{Q}$-type channels by $\mathrm{G}$-proteins has a time constant of $\sim 100 \mathrm{msec}$ in chromaffin cells (Currie and Fox, 1997), which is significantly faster than the $400 \mathrm{msec}$ interpulse duration used in our studies. Therefore, at the high stimulus frequencies that can occur in vivo when an animal is in danger and the fight-or-flight response is activated, purinoceptor inhibition of catecholamine secretion may be virtually abolished by a combination of these two mechanisms.

Chromaffin cells costore and secrete various neuromodulators with catecholamines, including ATP (Winkler and Westhead, 1980). The functional role of ATP in secretory vesicles has recently become the focus of much interest. Evidence suggesting that ATP forms part of an autocrine inhibitory loop controlling $\mathrm{Ca}^{2+}$ channels has been provided by several studies (Albillos et al., 1996; Currie and Fox, 1996; Carabelli et al., 1998). The results of this study show that P2Y purinoceptors inhibit stimulus-evoked exocytosis in chromaffin cells as a direct consequence of $\mathrm{G}_{\mathrm{i} / \mathrm{o}}$-protein inhibition of $\mathrm{Ca}^{2+}$ channels and the $\mathrm{Ca}^{2+}$ signals regulating vesicle fusion rather than a direct effect on the exocytotic machinery. Presynaptic P2Y purinoceptors in the brain and periphery may act in a similar manner to regulate exocytosis of catecholamines, as well as other transmitters.

\section{REFERENCES}

Albillos A, Gandía L, Michelena P, Gilabert JA, Del Valle M, Carbone E, García AG (1996) The mechanism of calcium channel facilitation in bovine chromaffin cells. J Physiol (Lond) 494:687-695.

Artalejo CR, Adams ME, Fox AP (1994) Three types of $\mathrm{Ca}^{2+}$ channel trigger secretion with different efficacies in chromaffin cells. Nature 367:72-76.

Boehm S (1999) ATP stimulates sympathetic transmitter release via presynaptic P2X purinoceptors. J Neurosci 19:737-746.

Boeynaems J-M, Communi D, Janssens R, Motte S, Robaye B, Pirotton S (1998) Nucleotide receptors coupling to the phospholipase C signaling pathway. In: The P2 nucleotide receptors (Turner JT, Weisman GA, Fedan JS, eds), pp 169-183. Totowa, NJ: Humana.

Bourinet E, Soong TW, Sutton KG, Slaymaker SJ, Mathews E, Monteil A, Zamponi GW, Nargeot J, Snutch TP (1999) Splicing of $\alpha_{1 \mathrm{~A}}$ subunit gene generates phenotypic variants of P- and Q-type calcium channels. Nat Neurosci 2:407-415.

Brody DL, Patil PG, Mulle JG, Snutch TP, Yue DT (1997) Bursts of action potential waveforms relieve G-protein inhibition of recombinant P/Q-type $\mathrm{Ca}^{2+}$ channels in HEK 293 cells. J Physiol (Lond) 499:637-644.

Carabelli V, Carra I, Carbone E (1998) Localized secretion of ATP and opioids revealed through single $\mathrm{Ca}^{2+}$ channel modulation in bovine chromaffin cells. Neuron 20:1255-1268.

Catterall WA (1999) Interactions of presynaptic $\mathrm{Ca}^{2+}$ channels and SNARE proteins in neurotransmitter release. Ann NY Acad Sci 868:144-159.

Chow RH, Klingauf J, Heinemann C, Zucker RS, Neher E (1996) Mechanisms determining the time course of secretion in neuroendocrine cells. Neuron 16:369-376.

Currie KP, Fox AP (1996) ATP serves as a negative feedback inhibitor of voltage-gated $\mathrm{Ca}^{2+}$ channel currents in cultured bovine adrenal chromaffin cells. Neuron 16:1027-1036.

Currie KPM, Fox AP (1997) Comparison of N- and P/Q-type voltagegated calcium channel current inhibition. J Neurosci 17:4570-4579.

Diverse-Pierluissi M, Dunlap K, Westhead EW (1991) Multiple actions of extracellular ATP on calcium currents in cultured bovine chromaffin cells. Proc Natl Acad Sci USA 88:1261-1265.

Dolphin AC (1998) Mechanisms of modulation of voltage-dependent calcium channels by $\mathrm{G}$ proteins. J Physiol (Lond) 506:3-11.

Douglas WW, Poisner AM (1966) On the relation between ATP splitting and secretion in the adrenal chromaffin cell: extrusion of ATP (unhydrolyzed) during release of catecholamines. J Physiol (Lond) 183:249-256.

Dunlap K, Luebke JI, Turner TJ (1995) Exocytotic $\mathrm{Ca}^{2+}$ channels in mammalian central neurons. Trends Neurosci 18:89-98.

Edwards AV (1982) Adrenal catecholamine output in response to stimulation of the splanchnic nerve in bursts in the conscious calf. J Physiol (Lond) 327:409-419.

Edwards AV, Furness PN, Helle KB (1980) Adrenal medullary responses to stimulation of the splanchnic nerve in the conscious calf. J Physiol (Lond) 308:15-27.

Edwards FA, Gibb AJ, Colquhoun D (1992) ATP receptor-mediated synaptic currents in the central nervous system. Nature 359:144-147.

Engisch KL, Nowycky MC (1996) Calcium dependence of large densecored vesicle exocytosis evoked by calcium influx in bovine adrenal chromaffin cells. J Neurosci 16:1359-1369.

Engisch KL, Chernevskaya NI, Nowycky MC (1997) Short-term changes in the $\mathrm{Ca}^{2+}$-exocytosis relationship during repetitive pulse protocols in bovine adrenal chromaffin cells. J Neurosci 17:9010-9025.

Evans RJ, Derkach V, Surprenant A (1992) ATP mediates fast synaptic transmission in mammalian neurons. Nature 357:503-505.

Fidler N, Fernandez JM (1989) Phase tracking: an improved phase detection technique for cell membrane capacitance measurements. Biophys J 56:1153-1162.

Gandia L, Garcia AG, Morad M (1993) ATP modulation of calcium channels in chromaffin cells. J Physiol (Lond) 470:55-72.

Gibb AJ, Halliday FC (1996) Fast purinergic transmission in the central nervous system. Semin Neurosci 8:225-232.

Grynkiewicz G, Peonie M, Tsien RY (1985) A new generation of $\mathrm{Ca}^{2+}$ indicators with greatly improved fluorescence properties. J Biol Chem 260:3440-3450.

Heinemann C, Chow RH, Neher E, Zucker RS (1994) Kinetics of the secretory response in bovine chromaffin cells following flash photolysis of caged $\mathrm{Ca}^{2+}$. Biophys J 67:2546-2557. 
Hille B (1994) Modulation of ion-channel by G-protein-coupled receptors. Trends Neurosci 17:531-536.

Horrigan FT, Bookman RJ (1994) Releasable pools and the kinetics of exocytosis in adrenal chromaffin cells. Neuron 13:1119-1129.

Jeong S-W, Ikeda SR (1999) Sequestration of G-protein $\beta \gamma$ subunits by different G-protein $\alpha$ subunits blocks voltage-dependent modulation of $\mathrm{Ca}^{2+}$ channels in rat sympathetic neurons. J Neurosci 19:4755-4761.

Khakh BS, Henderson G (1998) ATP receptor-mediated enhancement of fast excitatory neurotransmitter release in the brain. Mol Pharmacol. 54:372-378.

Lang J, Nishimoto I, Okamoto T, Regazzi R, Kiraly C, Weller U, Wollheim CB (1995) Direct control of exocytosis by receptor-mediated activation of the heterotrimeric GTPases $G_{i}$ and $G_{o}$ or by the expression of their active $\mathrm{G} \alpha$ subunits. EMBO J 14:3635-3644.

Lara B, Gandia L, Martinez-Sierra R, Torres A, Garcia AG (1998) Q-type $\mathrm{Ca}^{2+}$ channels are located closer to secretory sites than L-type channels: functional evidence in chromaffin cells. Pflügers Arch 435:472-478

Lim W, Kim SJ, Yan HD, Kim J (1997) $\mathrm{Ca}^{2+}$-channel-dependent and -independent inhibition of exocytosis by extracellular ATP in voltageclamped rat adrenal chromaffin cells. Pflügers Arch 435:34-42.

Linial M, Ilouz N, Parnas H (1997) Voltage-dependent interaction between the muscarinic ACh receptor and proteins of the exocytic machinery. J Physiol (Lond) 504:251-258.

Lomax RB, Michelena P, Nunez L, Garcia-Sancho J, Garcia AG, Montiel C (1997) Different contributions of L- and Q-type $\mathrm{Ca}^{2+}$ channels to $\mathrm{Ca}^{2+}$ signals and secretion in chromaffin cell subtypes. Am J Physiol 272:C476-C484.

MacDermott AB, Role LW, Siegelbaum SA (1999) Presynaptic ionotropic receptors and the control of transmitter release. Annu Rev Neurosci 22:443-485.

ManSonHing H, Zoran MJ, Lukowiak K, Haydon PG (1989) A neuromodulator of synaptic transmission acts on the secretory apparatus as well as on ion channels. Nature 341:237-239.

Miller RJ (1998) Presynaptic receptors. Annu Rev Pharmacol Toxicol 38:201-227.

Mochida S, Yokoyama CT, Kim DK, Itoh K, Catterall WA (1998) Evidence for a voltage-dependent enhancement of neurotransmitter release mediated via the synaptic protein interaction site of $\mathrm{N}$-type $\mathrm{Ca}^{2+}$ channels. Proc Natl Acad Sci USA 95:14523-14528.

Neher E (1998) Vesicle pools and $\mathrm{Ca}^{2+}$ microdomains: new tools for understanding their roles in neurotransmitter release. Neuron 20:389-399.

Neher E, Zucker RS (1993) Multiple calcium-dependent processes related to secretion in bovine chromaffin cells. Neuron 10:21-30.

North RA, Barnard EA (1997) Nucleotide receptors. Curr Opin Neurobiol 7:346-357.

Page KM, Canti C, Stephens GJ, Berrow NS, Dolphin AC (1998) Identification of the amino terminus of neuronal $\mathrm{Ca}^{2+}$ channel $\alpha 1$ subunits $\alpha 1 \mathrm{~B}$ and $\alpha 1 \mathrm{E}$ as an essential determinant of G-protein modulation. J Neurosci 18:4815-4824.

Park D, Dunlap K (1998) Dynamic regulation of calcium influx by G-proteins, action potential waveform, and neuronal firing frequency. J Neurosci 18:6757-6766.

Parsons TD, Ellis-Davies GCR, Almers W (1996) Millisecond studies of calcium-dependent exocytosis in pituitary melanotrophs: comparison of the photolabile calcium chelators nitrophenyl-EGTA and DM-nitrophen. Cell Calcium 19:185-192.
Rusin KI, Giovannucci DR, Stuenkel EL, Moises HC (1997) $\kappa$-opioid receptor activation modulates $\mathrm{Ca}^{2+}$ currents and secretion in isolated neuroendocrine nerve terminals. J Neurosci 17:6565-6574.

Seward EP, Nowycky MC (1996) Kinetics of stimulus-coupled secretion in dialyzed bovine chromaffin cells in response to trains of depolarizing pulses. J Neurosci 16:553-562.

Seward EP, Chernevskaya NI, Nowycky MC (1995) Exocytosis in peptidergic nerve terminals exhibits two calcium-sensitive phases during pulsatile calcium entry. J Neurosci 15:3390-3399.

Seward EP, Chernevskaya NI, Nowycky MC (1996) $\mathrm{Ba}^{2+}$ ions evoke two kinetically distinct patterns of exocytosis in chromaffin cells, but not neurohypophysial nerve terminals. J Neurosci 16:1370-1379.

Shen KZ, Surprenant A (1990) Mechanisms underlying presynaptic inhibition through alpha2-adrenoceptors in guinea-pig submucosal neurones. J Physiol (Lond) 431:609-628.

Silinsky EM (1986) Inhibition of transmitter release by adenosine: are $\mathrm{Ca}^{2+}$ currents depressed or are the intracellular effects of $\mathrm{Ca}^{2+}$ impaired? Trends Pharmacol 7:180-185.

Smith C (1999) A persistent activity-dependent facilitation in chromaffin cells is caused by $\mathrm{Ca}^{2+}$ activation of protein kinase C. J Neurosci 19:589-598.

Takahashi T, Forsythe ID, Tsujimoto T, Barnes-Davies M, Onodera K (1996) Presynaptic calcium current modulation by a metabotropic glutamate receptor. Science 274:594-597.

Thomas P, Surprenant A, Almers W (1990) Cytosolic Ca ${ }^{2+}$, exocytosis, and endocytosis in single melanotrophs of the rat pituitary. Neuron 5:723-733.

Thompson SM, Capogna M, Scanziani M (1993) Presynaptic inhibition in the hippocampus. Trends Neurosci 16:222-227.

Trifaro JM, Lee RWH (1981) Characterization of anti-actin antibodies and their use in immunocytochemical studies on the localization of actin in adrenal chromaffin cells in culture. Neuroscience 6:2087-2108.

Von Kügelgen I (1996) Modulation of neural ATP release through presynaptic receptors. Semin Neurosci 8:247-257.

Von Kügelgen I, Schoffel E, Starke K (1989) Inhibition by nucleotides acting at presynaptic P2-receptors of sympathetic neuro-effector transmission in the mouse isolated vas deferens. Naunyn Schmiedebergs Arch Pharmacol 340:522-532.

Von Kügelgen I, Kurz K, Starke K (1994) P2-purinoceptor-mediated autoinhibition of sympathetic transmitter release in mouse and rat vas deferens. Naunyn Schmiedebergs Arch Pharmacol 349:125-132.

von Ruden L, Neher E (1993) A Ca-dependent early step in the release of catecholamines from adrenal chromaffin cells. Science 262:1061-1065.

Winkler H, Westhead EW (1980) The molecular organisation of adrenal chromaffin granules. Neuroscience 5:1803-1823.

Wu LG, Saggau P (1997) Presynaptic inhibition of elicited neurotransmitter release. Trends Neurosci 20:204-212.

Xu T, Binz T, Neimann H, Neher E (1998) Multiple kinetic components of exocytosis distinguished by neurotoxin sensitivity. Nat Neurosci $1: 192-200$.

Zamponi GW, Snutch TP (1998) Modulation of voltage-dependent calcium channels by $\mathrm{G}$ proteins. Curr Opin Neurobiol 8:351-356.

Zhou Z, Misler S (1995) Action potential-induced quantal secretion of catecholamines from rat adrenal chromaffin cells. J Biol Chem 270:3498-3505.

Zimmermann H (1994) Signalling via ATP in the nervous system. Trends Neurosci 17:420-426. 